\title{
Innovative MIOR Process Utilizing Indigenous Reservoir Constituents
}

\author{
By \\ D. O. Hitzman \\ A. K. Stepp \\ D. M. Dennis \\ L. R. Graumann \\ April 2002 \\ Semi-Annual Report
}

\section{Work Performed Under Contract DE-AC26-99BC15214}

Prepared for

U.S. Department of Energy

Assistant Secretary for Fossil Energy

Virginia Weyland, Project Manager

National Petroleum Technology Office

P.O. Box 3628

Tulsa, OK 74101

Prepared by:

Geo-Microbial Technologies, Inc.

East Main Street

Ochelata, Oklahoma 74051 


\section{DISCLAIMER}

This report was prepared as an account of work sponsored by an agency of the United States Government. Neither the United States Government nor any agency thereof, nor any of their employees, makes any warranty, express or implied, or assumes any legal liability or responsibility for the accuracy, completeness, or usefulness of any information, apparatus, product, or process disclosed, or represents that its use would not infringe privately owned rights. Reference herein to any specific commercial product, process, or service by trade name, trademark, manufacturer, or otherwise does not necessarily constitute or imply its endorsement, recommendation, or favoring by the United States Government or any agency thereof. The views and opinions of authors expressed herein do not necessarily state or reflect those of the United States Government or any agency thereof. 


\section{TABLE OF CONTENTS}

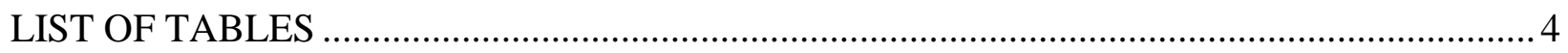

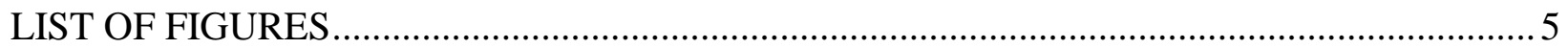

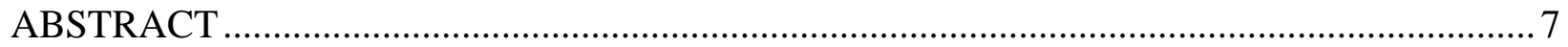

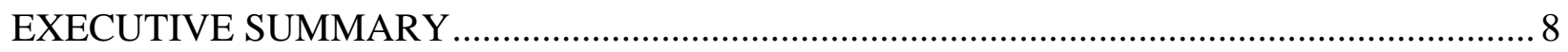

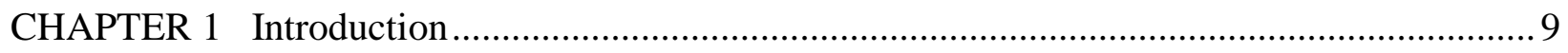

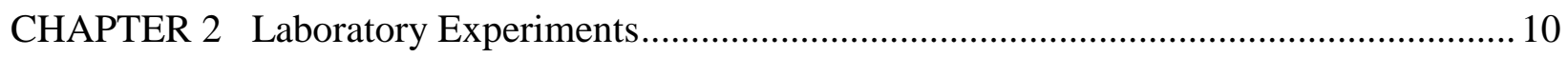

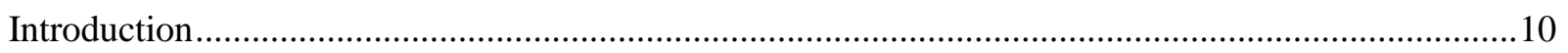

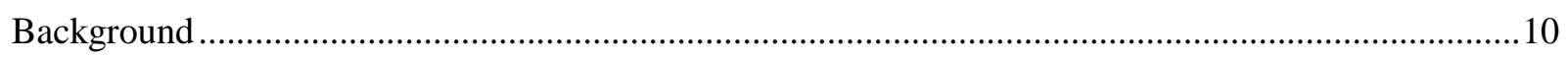

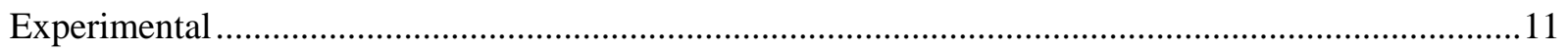

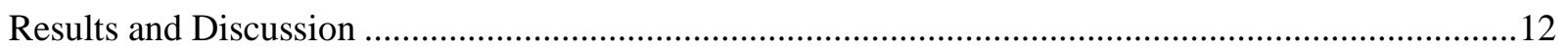

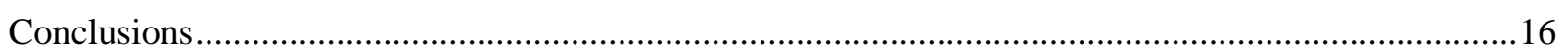

CHAPTER 3 Field Evaluation of New Technology/Products .................................................... 17

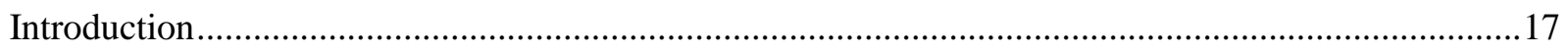

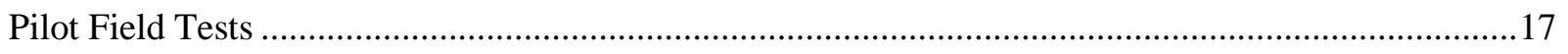

CHAPTER 4 Reports and Technology Transfer......................................................................... 36

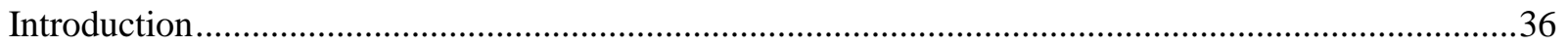

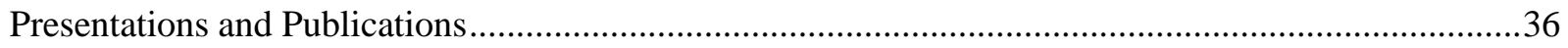

Presentations as part of GMT Exhibit Booth ...............................................................................36

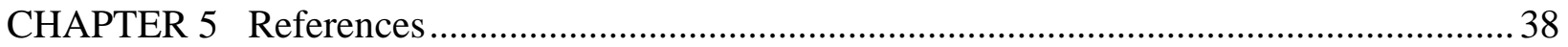




\section{LIST OF TABLES}

Table 1. Brine analysis.

12

Table 2. Sand packs. 


\section{LIST OF FIGURES}

Figure 1. Comparison of dry vs. liquid nutrient in Tulare produced brine.

Figure 2. Comparison of dry vs. liquid nutrient in Tulare aquifer water.

Figure 3. Comparison of dry vs. liquid nutrient in Ventura produced brine.

Figure 4. Comparison of dry vs. liquid nutrient in Diatamite produced brine.

Figure 5. HO-101 sandpack flood.

Figure 6. HO-102 sandpack flood.

Figure 7. HO-103 sandpack flood.

Figure 8. Lost Hills field test area.

Figure 9. Combined production for nine test wells, Mar. 20-Sept 30, 2001.

Figure 10. Test well production Mar. 20-Sept. 30, 2001.

Figure 11. Combined production for seven control wells, Mar. 20-Sept 30, 2001.

Figure 13. Belridge control well 7284A.

Figure 14. Belridge control well 7287A.

Figure 15. Belridge control well 7307A.

Figure 16. Belridge control well 7313.

Figure 17. Belridge control well 7329.

Figure 18. Belridge control well 7355A.

Figure 19. Belridge control well 7361B.

Figure 20. Belridge control well 7383.

Figure 21. Belridge control well 7406. 
Figure 22. Belridge control well 7409.

Figure 23. Belridge test well 7283.

Figure 24. Belridge test well 7283A.

Figure 25. Belridge test well 7285A.

Figure 26. Belridge test well 7306A.

Figure 27. Belridge test well 7309A.

Figure 28. Belridge test well 7310A. 28

Figure 29. Belridge test well 7310B.

Figure 30. Belridge test well 7311A.

Figure 31. Belridge test well 7312.

Figure 32. Belridge test well 7332A.

Figure 33. Belridge test well 7333.

Figure 34. Belridge test well 7333B.

Figure 35. Belridge test well 7334A.

Figure 36. Belridge test well 7335.

Figure 37. Belridge test well 7337.

Figure 38. Belridge test well 7359A.

Figure 39. Belridge test well 7361A.

Figure 40. Belridge test well 7404.

Figure 41. Belridge test well 7407.

Figure 42. Belridge test well 8383. 


\section{ABSTRACT}

This research program is directed at improving the knowledge of reservoir ecology and developing practical microbial solutions for improving oil production. The goal is to identify indigenous microbial populations which can produce beneficial metabolic products and develop a methodology to stimulate those select microbes with nutrient amendments to increase oil recovery. This microbial technology has the capability of producing multiple oil-releasing agents.

Research has begun on the program and experimental laboratory work is underway. Microbial cultures have been isolated from produced water samples and initially characterized.

Comparative laboratory studies demonstrating in situ production of microbial products as oil recovery agents were conducted in sand packs with natural field waters with cultures and conditions representative of oil reservoirs. Two field pilot studies are now underway. 


\section{EXECUTIVE SUMMARY}

This project is an experimental laboratory study designed to improve the understanding of reservoir ecology, and to establish methods of manipulating indigenous microorganisms that utilize naturally occurring water soluble organic acids to produce beneficial oil recovery agents. The objectives of this research program are to demonstrate in-situ production of oil recovery agents in reservoir waters by indigenous microbial populations, and to enhance and control the content and concentration of the bioproducts by the selective addition of low concentrations of inorganic salts as an alternate electron system.

The research program has been divided into a series of seven tasks that are designed to determine the feasibility of developing a practical and cost effective in-situ microbial system for increasing the effectiveness of oil-recovery agents in oil reservoirs. Research in this program will focus on stimulating in situ microbial products to enhance oil recovery. Experimental work on the project begins in Task 1 with selection of suitable microbial strains and development of test procedures for subsequent studies. Research in Task 2 has developed physical models which have been used to quantify improved oil production in porous media. The objective of Task 3 is to demonstrate that nutrient amendments can be used to selectively stimulate microbes to produce oil-releasing agents. Results from Tasks 1 through 3 were applied to Task 4 for inclusion into an increased oil recovery system. This task has been incorporated in conjunction with the preceding flooding tests. Task 4 tests comprise a significant portion of the test program and involve demonstrating and optimizing the effectiveness of the oil recovery biosystem. Data from experimental work has been correlated and integrated for the effects of the biosystems on oil recovery in Task 5, and reported in a form which could be offered for technology transfer to the oil industry for commercial applications. As results are obtained from the laboratory investigations and are made available to field operations through technology transfer, work in Task 6 has been directed toward applying the new technology to field studies, situations, and operations. This approach provides rapid introduction and evaluation of any system and/or product which is developed by this program, and will allow directly comparable data to be collected. Technical reports have been prepared under Task 7.

The described research project was designed as a three-year experimental study. Work on the project commenced on October 1, 1999 and research projects were initiated as planned at that time. Active experimental projects are now in progress in all Tasks. Samples of produced water have been obtained from actively producing fields and enriched for selective microorganisms. Several promising strains of microbes have been isolated and are currently being used for experimental work. Microcosm scale sand-packed columns were designed and tested for developing selected cultures by nutrient stimulation. Experimental design of flooding regimes is in progress to test the effects of nutrient stimulation on oil recovery in physical models. No problems have been encountered in the project to date. 


\section{CHAPTER 1 \\ Introduction}

It is known that microorganisms can survive and multiply in and under reservoir conditions, and have the capability to significantly influence oil practices and production (credited to Beckman, 1926). Using such data, it has been proposed that microorganisms can also exert and have a positive effect on oil production $(1,2)$. Areas being actively studied include the production of biopolymers and biosurfactants by microorganisms, and the injection of these products for viscosity and surface tension modifications. In addition, microorganisms have been tested for their ability to grow in oil reservoirs and by their growth in-situ cause the increased mobilization of oil through various mechanisms and/or products such as $\mathrm{CO}_{2}$ and other gases, surfactants, organic acids and solvents. Successful field tests employing Microbial Improved Oil Recovery (MIOR) technologies have been reported and more field tests are now in progress (3).

More recently it has been shown that the presence of inorganic nutrients can control reservoir ecology, and adding inorganic nutrients as alternate electron acceptors can stimulate distinct groups of bacteria (4). Several discoveries resulting from this understanding of reservoir ecology are of key importance for the present research project:

- Low concentrations of selected nitrogen salts stimulate populations of indigenous denitrifying microbes,

- Such denitrifying populations are heterotrophs known to produce copious amounts of biopolymers and biosurfactants at reservoir conditions,

- Beneficial microbial populations can be established and maintained within the reservoir by supplying low-cost nitrogen salts.

This line of investigation has been expanded in the present research program to develop an understanding of a methodology to use low-cost inorganic nutrient amendments that stimulate indigenous microflora to utilize natural reservoir constituents to produce beneficial products. The three-year research project began in October 1999. This report describes month twenty-five through month thirty of the project. Chapter 2 describes the laboratory experiments, including selection of suitable microbial strains, isolation of cultures from oil field brines and other sources, and nutrient studies. Design and development of physical models for studying fluid flow is also detailed, as well as sand pack flood results. Physical models were used to test the concepts of controlled microbial ecology for creating an improved oil recovery system. Several sand pack floods were completed. Most of the research effort is now concentrated on oil recovery tests.

Chapter 3 details the two field pilot tests currently underway. Chapter 4 describes the work thus far on reports and technology transfer. 


\section{CHAPTER 2}

\section{Laboratory Experiments}

\section{Introduction}

Oil reservoirs contain diverse microbial populations, including species introduced during drilling and production activities, and species native to the reservoir environment. Except in cases of extreme biological constraint (i.e., temperature, salt, etc.), oil reservoirs establish indigenous microbial communities which adapt to the prevailing reservoir conditions. These complex microbial communities contain the metabolic capabilities to produce known oil recovery agents such as biosurfactants and biopolymers. The indigenous communities are in dynamic equilibrium with their environment, and can be restructured in a directed way to favor production of beneficial products. The presence of inorganic nutrients can control reservoir ecology, and adding inorganic nutrients as alternate electron acceptors can stimulate distinct groups of bacteria. The in situ metabolic activity of these select bacteria results in several bioproducts that effectively release trapped residual oil.

This research program focuses on developing an understanding of a methodology to use low-cost inorganic nutrient amendments that stimulate indigenous microflora to utilize natural reservoir constituents to produce beneficial products. In order to assess effects that the distinct physiological groups have on oil mobilization, it is necessary to develop procedures to measure the multiplicity of effects. Experimental work on the project began with selection of suitable microbial strains and development of test procedures for subsequent studies.

\section{Background}

Previous investigations of oilfield waters have endowed us with an extensive culture collection of oilfield microflora. Numerous cultures have been isolated from a wide range of field waters and facilities, including primary production wells and waterflooded fields, ranging from fresh waters to highly saline formation waters, and at various reservoir temperatures. The cultures have been isolated on varied media, and in particular the standard API acetate-lactate SRB (sulfate reducing bacteria) medium used widely by the oil industry. The collection has been supplemented with isolates from several other environmental sources including activated sewage sludge, polluted marine waters and sediments, naturally attenuated remediation sites, and historically contaminated production sites. Selected cultures from the collection were used as a primary source of inocula for enrichments.

The role of VFA as a key component which leads to the biogenic formation of sulfide in reservoirs was pioneered at GMT. These investigations led to the discovery of a novel technology which used the naturally occurring VFA in a beneficial role to prevent and remove sulfide in the reservoir. This patented technology causes the replacement of the detrimental SRB with a beneficial microbial population by the addition of a proprietary mixture of inorganic salts which act as an alternate electron acceptor. The technology which has been termed "Biocompetitive Exclusion" is based on the presence of VFA in the reservoir and its preferential use and removal by an indigenous microflora and therefore requires no addition of organisms. The growth of those anaerobic denitrifying microorganisms has the added potential of increasing oil recovery by the production of their metabolic products which can include gases $\left(\mathrm{CO}_{2}\right.$ and $\left.\mathrm{N}_{2}\right)$, biosurfactants, biopolymers, and acids. 
This past work which has identified VFA in oil field brines and which has shown its impact on reservoir souring and corrosion has led to the development of technologies which incorporate the VFA in a positive role. These previous experiments, field data, and results can be incorporated directly into this research effort. This research provides strong background information on VFA in reservoir fluids, and will be coupled with the ongoing studies of VFA in oil reservoirs to offer a unique information base for the successful completion of the program.

\section{Experimental}

\section{$\underline{\text { Bottle Tests }}$}

A new proprietary nutrient biosystem, referred to as Nutrient $\mathrm{T}$, is being developed. Bottle tests were conducted to test the system at different temperatures and with different oilfield brines from California. Water analysis for the brines is shown in Table 1. The system was also tested to compare a liquid version of the nutrient with a dry version. The tests were done in $50 \mathrm{ml}$ anaerobic serum bottles containing $20 \mathrm{ml}$ nutrient mixed with brine. The tests were run at $35^{\circ} \mathrm{C}$ and $55^{\circ} \mathrm{C}$. The bottles were checked periodically for gas production, which is a major product of this new biosystem.

Table 1. Brine analysis.

\begin{tabular}{|l|c|c|c|c|c|c|c|c|}
\hline \multicolumn{1}{|c|}{ Brine } & $\mathrm{pH}$ & $\begin{array}{c}\text { Total } \\
\text { Dissolved } \\
\text { Solids (\%) }\end{array}$ & $\begin{array}{c}\text { Iron } \\
(\mathrm{ppm})\end{array}$ & $\begin{array}{c}\text { Sulfate } \\
(\mathrm{ppm})\end{array}$ & SRB & DNB & GAB & $\begin{array}{c}\text { VFA } \\
(\mathrm{ppm})\end{array}$ \\
\hline $\begin{array}{l}\text { Tulare } \\
\text { produced }\end{array}$ & 6.5 & 1.2 & 5 & 234 & 2 & 0 & 3 & 14 \\
\hline $\begin{array}{l}\text { Tulare } \\
\text { aquifer }\end{array}$ & 7.1 & 1.7 & 2 & 33 & 4 & 5 & 3 & 0.5 \\
\hline Diatamite & 7.0 & 3.0 & 9 & 0 & 4 & 1 & 3 & 29 \\
\hline Ventura & 7.1 & 1.9 & 7 & 3 & 2 & 3 & 2 & 734 \\
\hline
\end{tabular}

\section{Oil Recovery Tests}

Three sand pack flooding experiments were conducted to determine the effects of various nutrients and flooding regimes on oil recovery. All experiments were conducted at $100^{\circ} \mathrm{F}\left(37.8^{\circ}\right.$ C). The sand pack columns were made of plastic, and were 2 inches $(5.08 \mathrm{~cm})$ in diameter and 10 feet $(3 \mathrm{~m})$ in length.

After saturation with Belridge field brine, oil saturation with Belridge heavy oil (viscosity 152 centipoise at $150^{\circ} \mathrm{F}$ ) obtained from a California oil field, and waterflooding to residual oil saturation, the packs were inoculated with a microbial consortium. The packs were shut in. Treatment was then begun with Max-Well 2000 nutrient mixed with Belridge brine. After oil production ceased with this nutrient treatment, the sand packs were treated with the new Nutrient $\mathrm{T}$ biosystem. Details for each pack are reported in Table 2. 
Table 2. Sand packs.

\begin{tabular}{|c|c|c|}
\hline Sand pack \# & PV $(\mathrm{ml})$ & OOIP $(\mathrm{ml})$ \\
\hline HO-101 & 2250 & 1643 \\
\hline HO-102 & 2000 & 1130 \\
\hline HO-103 & 2100 & 1930 \\
\hline
\end{tabular}

\section{Results and Discussion}

\section{Bottle Tests}

Results for the $55^{\circ} \mathrm{C}$ bottle tests, which gave better results than the $35^{\circ} \mathrm{C}$ tests, are shown in Figures 1-4. The data shown is cumulative gas production over time. Sampling for the liquid bionutrient system were discontinued after one month since the dry system had better results. This system is now being further developed to determine the optimum concentration and is being refined to a form which would be easier to work with in the oilfield.

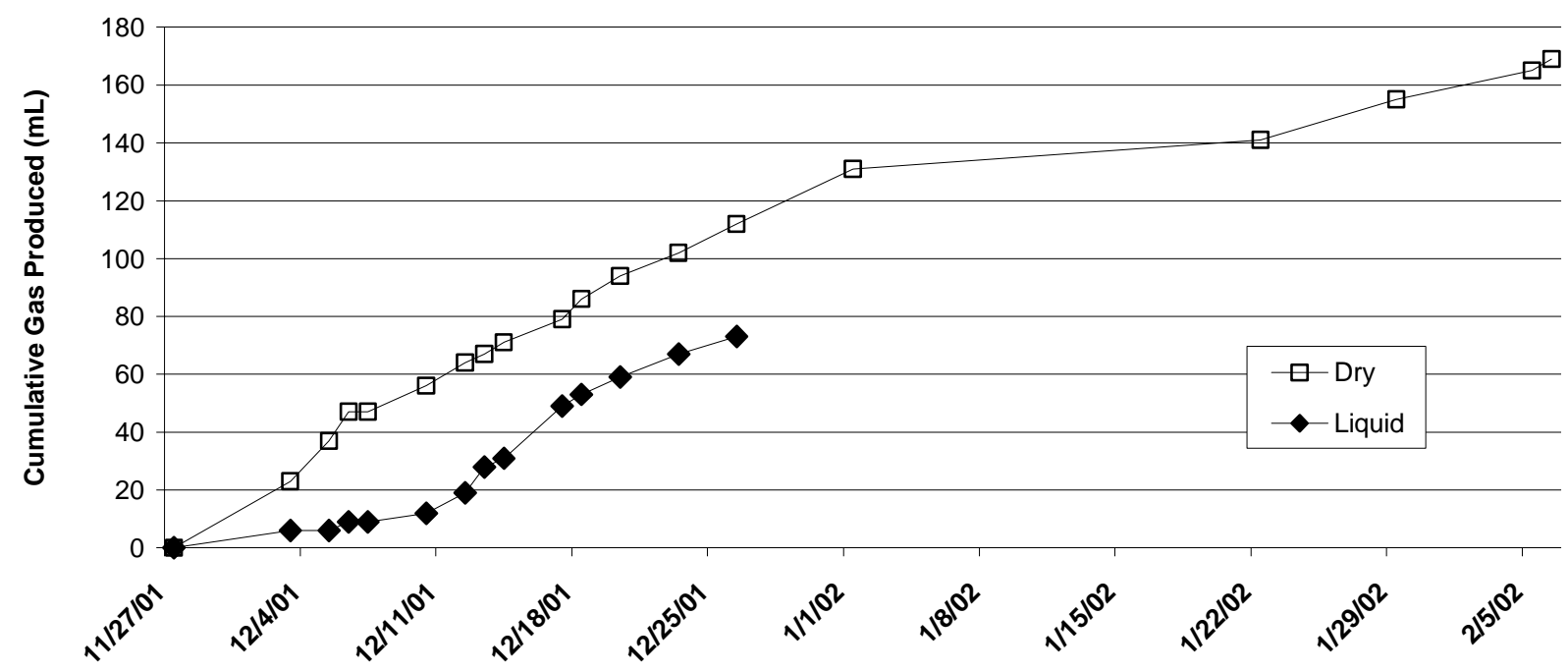

Figure 1. Comparison of dry vs. liquid nutrient in Tulare produced brine. 


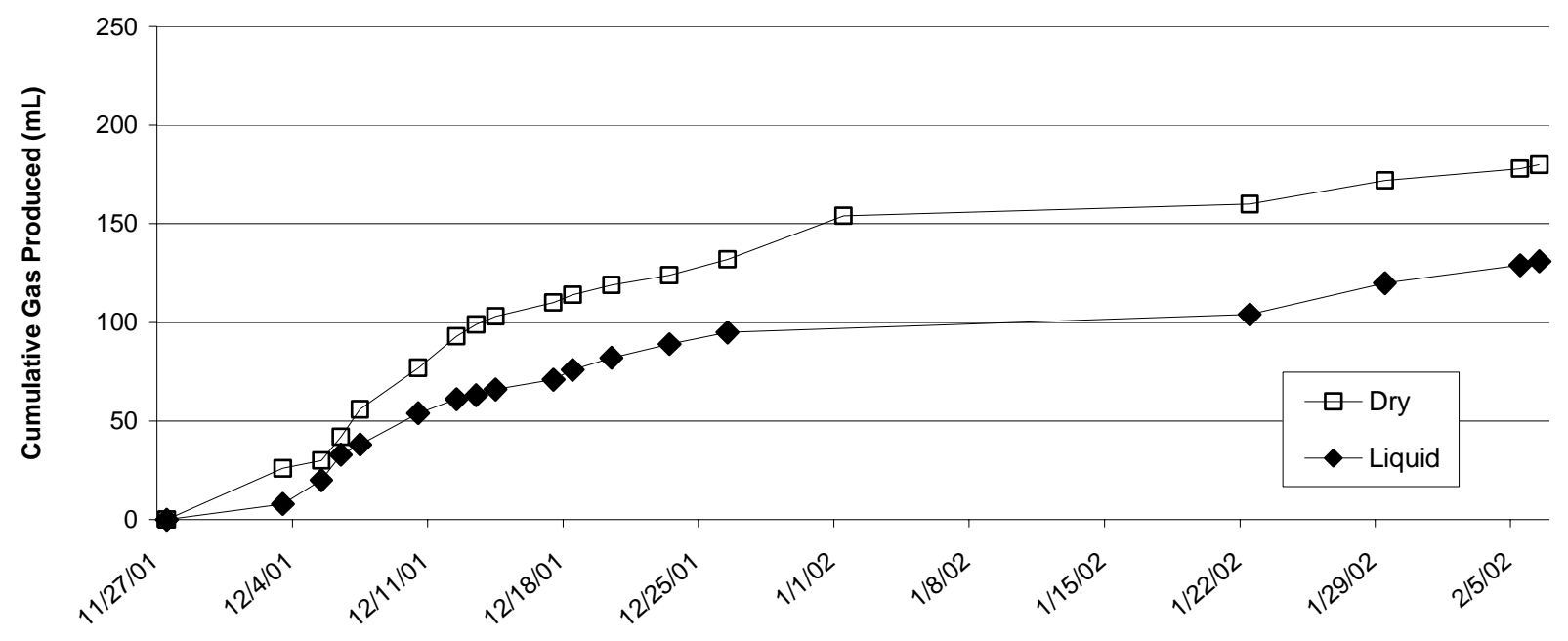

Figure 2. Comparison of dry vs. liquid nutrient in Tulare aquifer water.

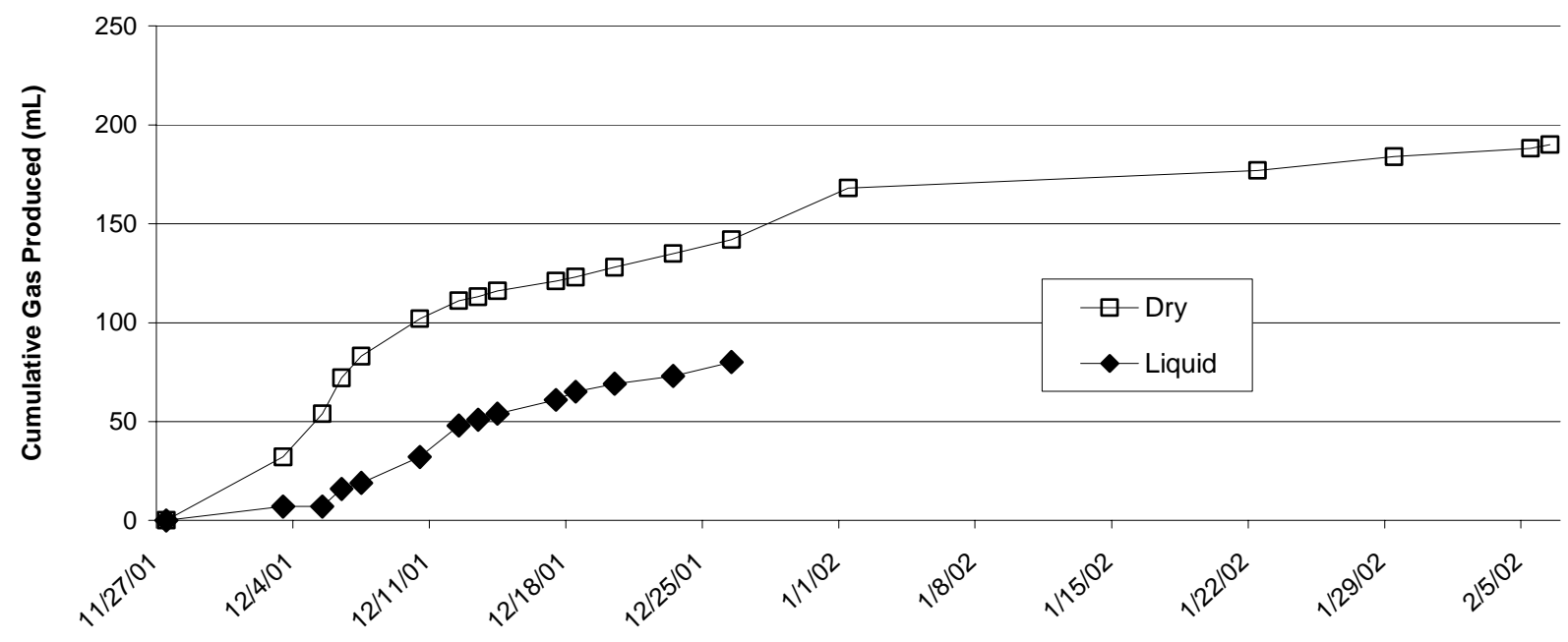

Figure 3. Comparison of dry vs. liquid nutrient in Ventura brine. 


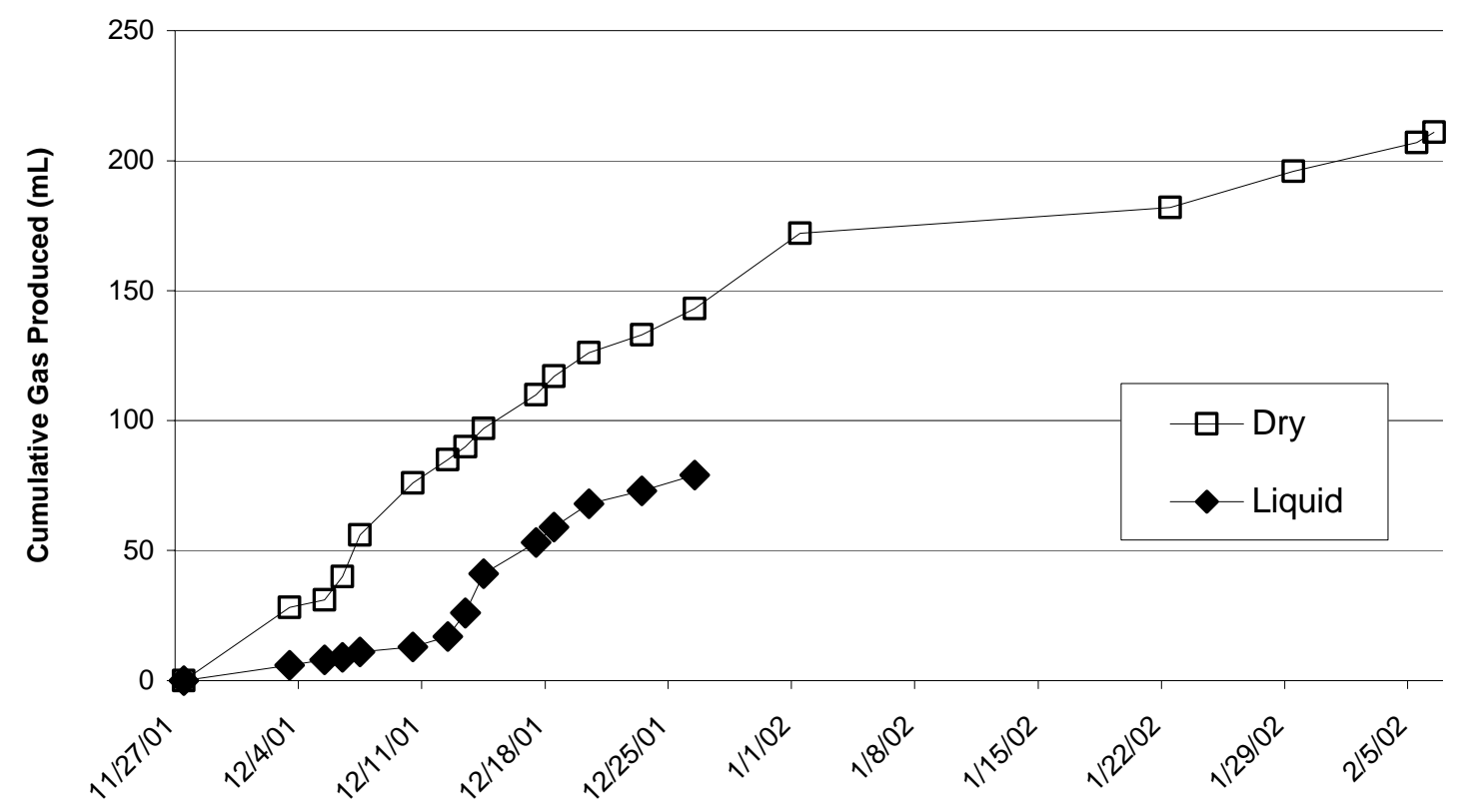

Figure 4. Comparison of dry vs. liquid nutrient in Diatamite brine.

\section{Oil Recovery Tests}

Results for the three sand pack floods are shown in Figures 5-7. Final oil recovery for sand pack HO-101 was 93\% of OOIP, for HO-102 the oil recovery was 94\%, and for HO-103 the oil recovery was $61 \%$. 


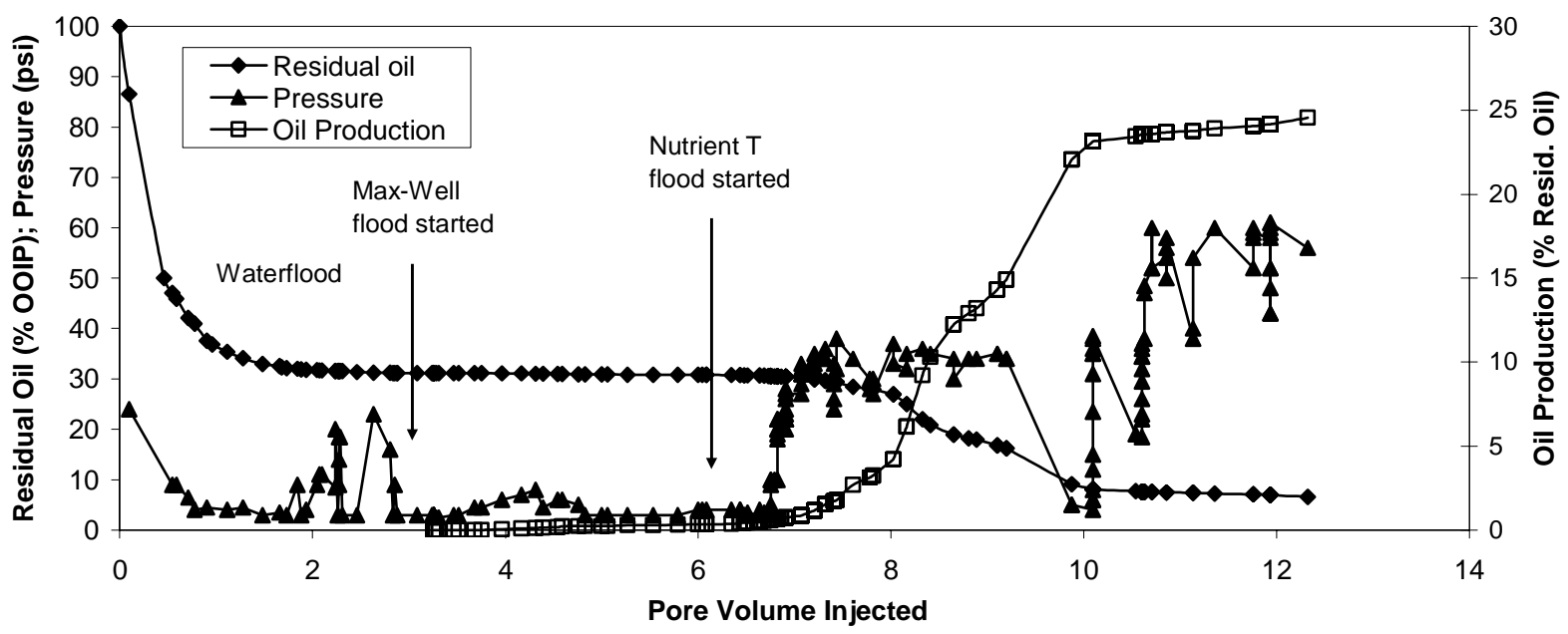

Figure 5. HO-101 sandpack flood.

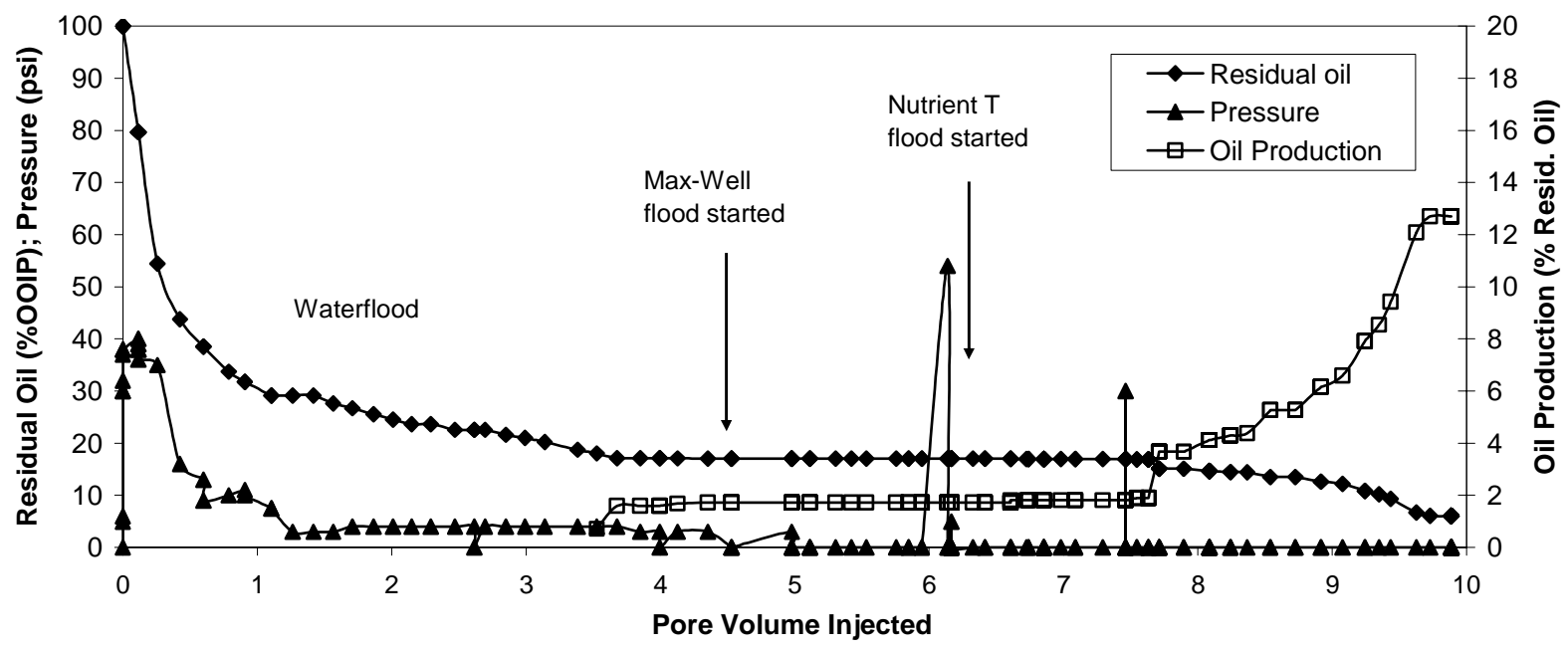

Figure 6. HO-102 sandpack flood. 


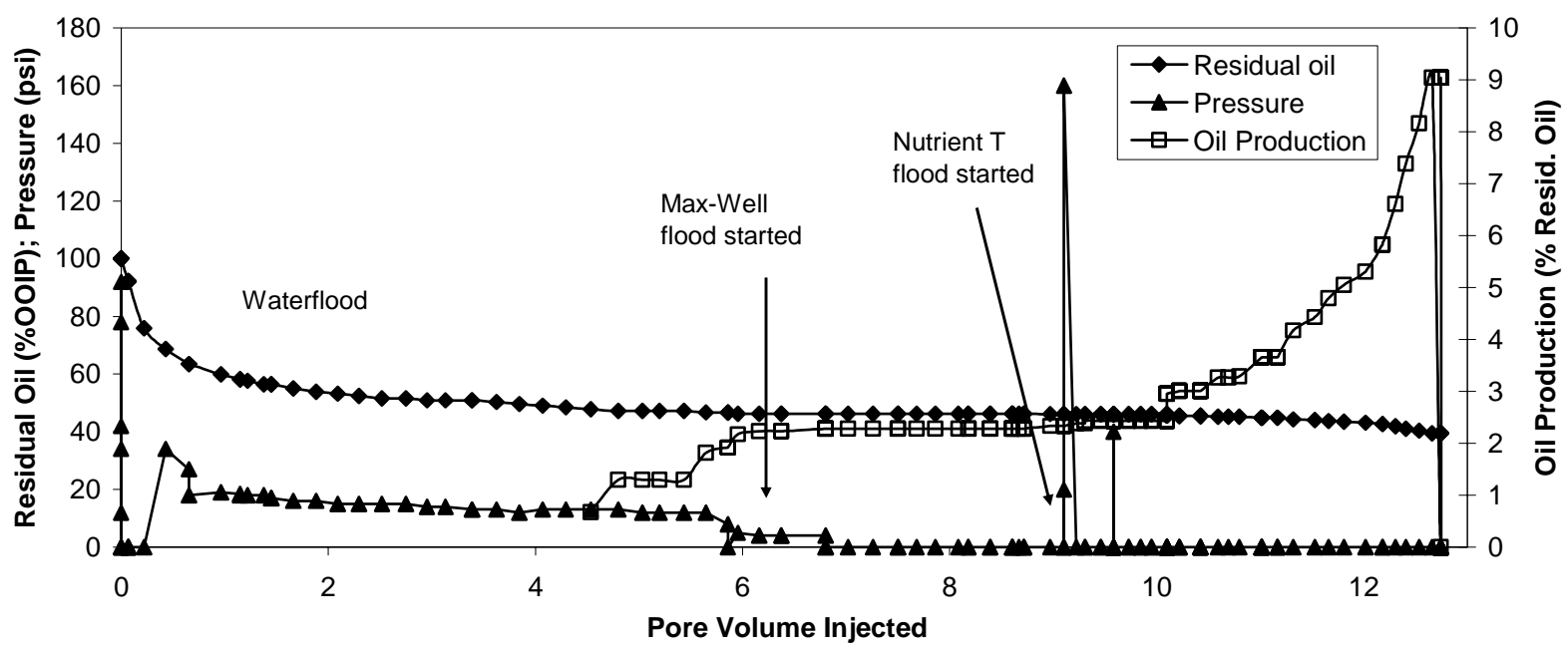

Figure 7. HO-103 sandpack flood.

\section{Conclusions}

- A new proprietary nutrient biosystem, referred to as Nutrient $\mathrm{T}$, is being developed. So far it shows promise in producing gas and mobilizing oil in sandpack experiments.

- The Nutrient T biosystem works well in all the field brines tried so far. 


\section{CHAPTER 3}

\section{Field Evaluation of New Technology/Products}

\section{Introduction}

As results have been obtained from the laboratory investigations and are made available to field operations through technology transfer, some of the findings have been offered and applied to field studies, situations, and operations. As the laboratory results are incorporated into pilot field projects, these field operations are being closely followed and monitored. The identifications of such fields and participation of the operators will provide additional feedback data from such projects. These pilot field evaluations are being conducted in conjunction with ongoing projects whenever possible. By utilizing such ongoing projects, the requirements for collection of baseline data, flood responses, field operations, etc. will be minimized. A pilot study has been implemented with operator assistance. This approach has allowed rapid introduction and evaluation of systems/products that have been developed by this program and provides directly comparable data. This method of field testing offers a low cost and easily approved and operated system to introduce the technology/products which have been developed in this research program.

\section{Pilot Field Tests}

Two field tests with Aera Energy are currently underway in California.

One field test was started in March 2001 in the Lost Hills field. The Lost Hills oil field was discovered in the early 1900's (1910 to 1915). Production has grown since that time. The zone associated with this microbial enhanced recovery is the deep marine diatomaceous shale. The very high porosity varies from 45 to $70 \%$ with a very low permeability of 0.1 to 3 millidarcies. Oil saturations vary from 30 to $60 \%$ with producing API gravities from 26 to 28 driven by a solution gas drive. The reservoir thickness varies from 700 to 1700 feet with the top of the formation varying from 1500 to 2300 feet from the surface.

The field has been waterflooded for several years. The test area, shown in Figure 8, includes a set of control wells (two injection wells and seven production wells) and a set of treatment wells (three injection wells and nine production wells). Treatment was started on March 20, 2001 using a proprietary blend of Max-Well 2000 product. The process relies on nutrient stimulation of the indigenous microbial population to produce oil-releasing byproducts such as nitrogen, carbon dioxide, methane, surfactants, solvents, and alcohols. The nutrient was injected continuously with the waterflood, which has a temperature of $100^{\circ} \mathrm{F}$. The test was terminated in October 2001 due to new drilling near the field and an injection well breaking through. Final results are shown in Figures 9-12. Oil production in the treated wells increased by $12.5 \%$ over the predicted production. Oil production in the control wells increased by $2.8 \%$ over the predicted production. 


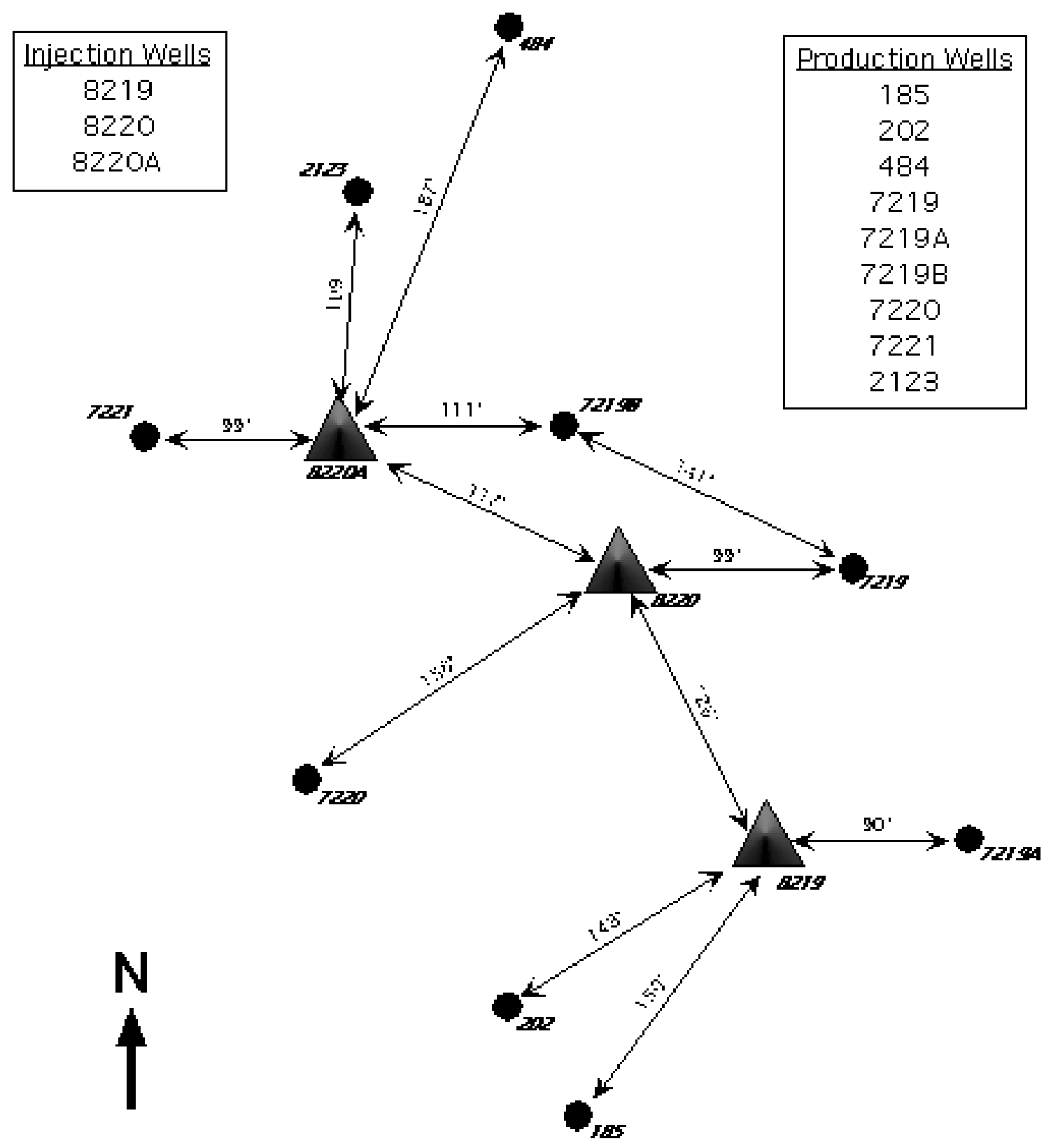

Figure 8. Lost Hills field test area. 


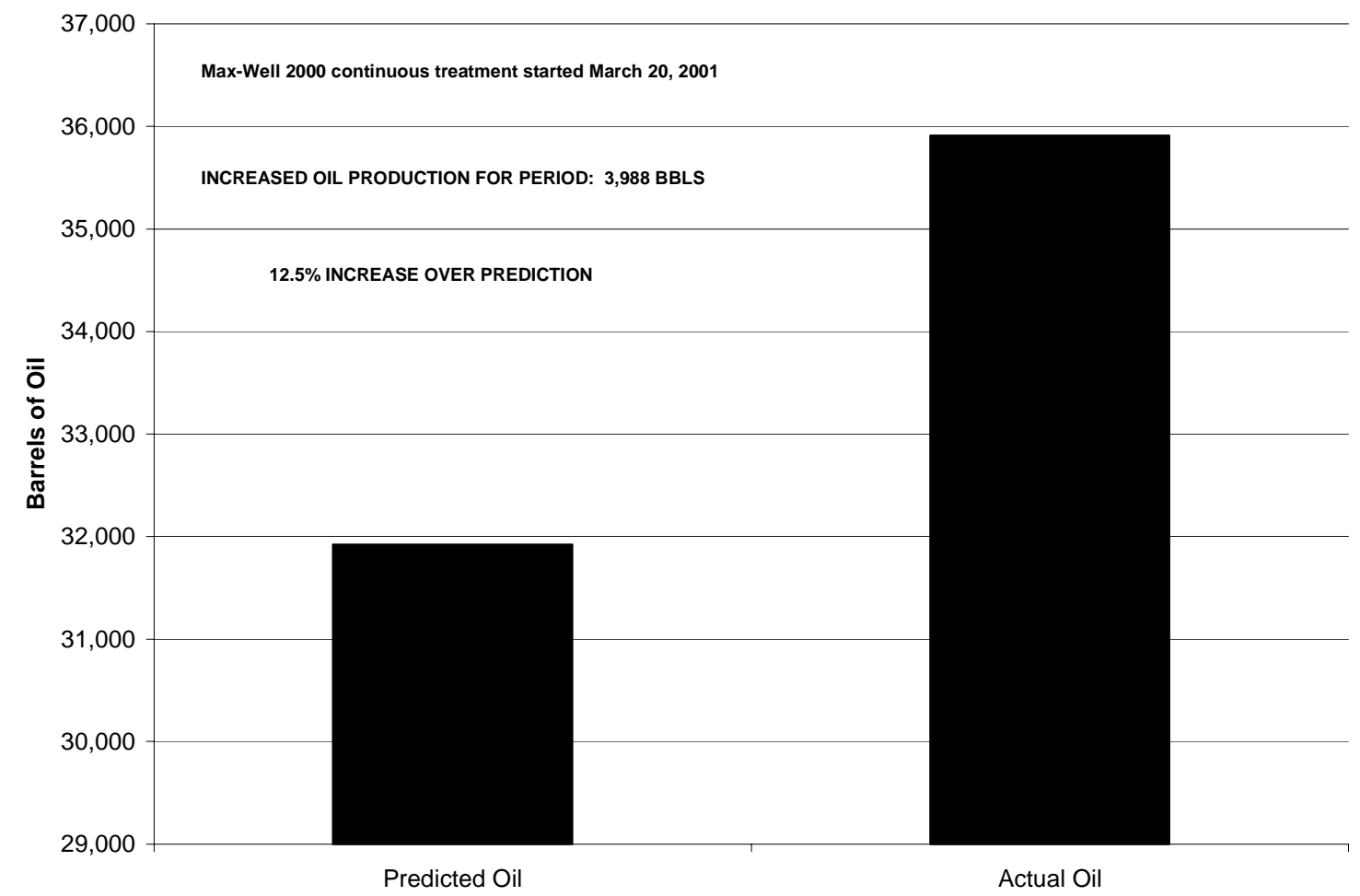

Figure 9. Combined production for nine test wells, Mar. 20 - Sept. 30, 2001.

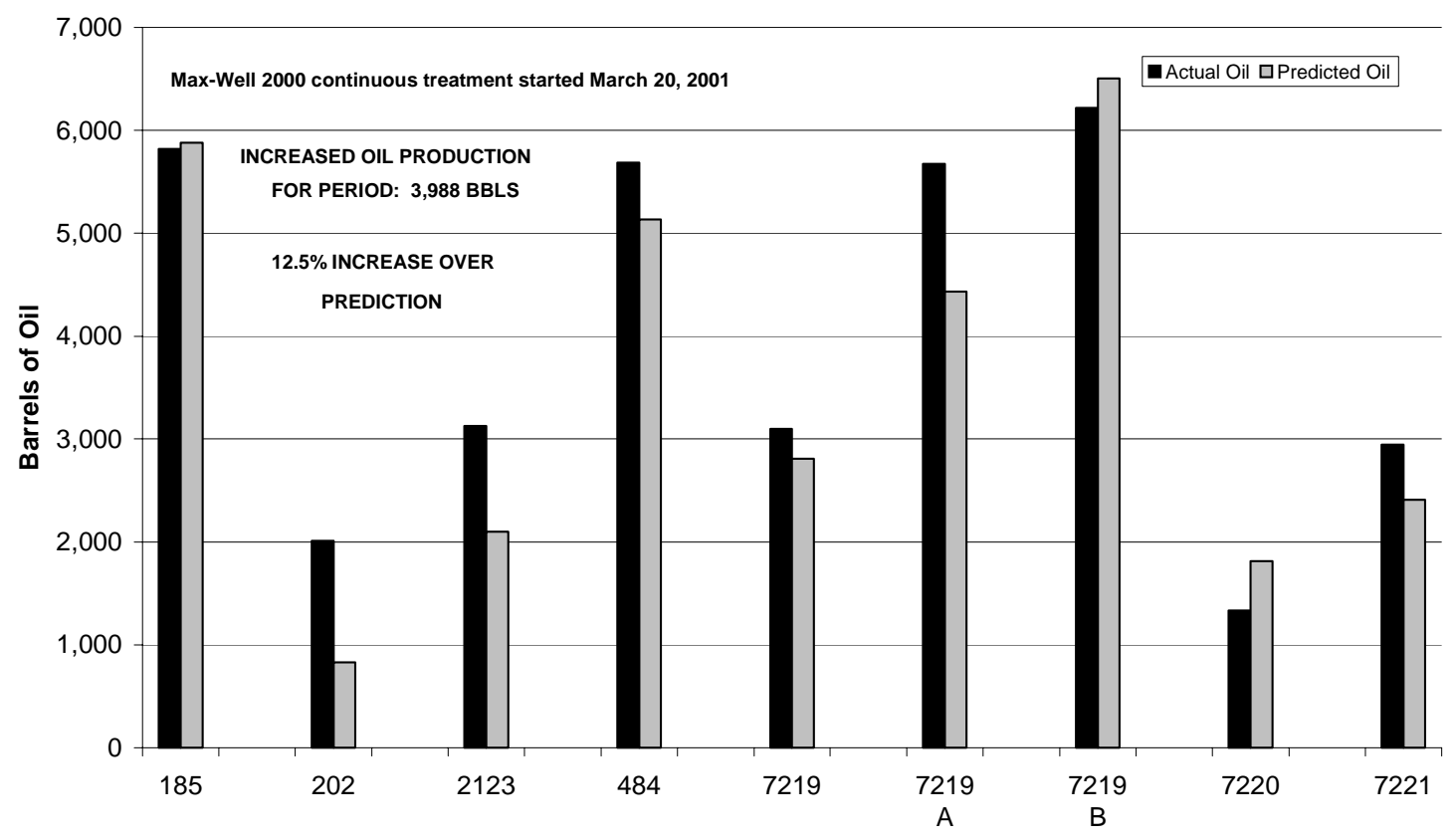

Figure 10. Test well production Mar. 20 - Sept. 30, 2001. 


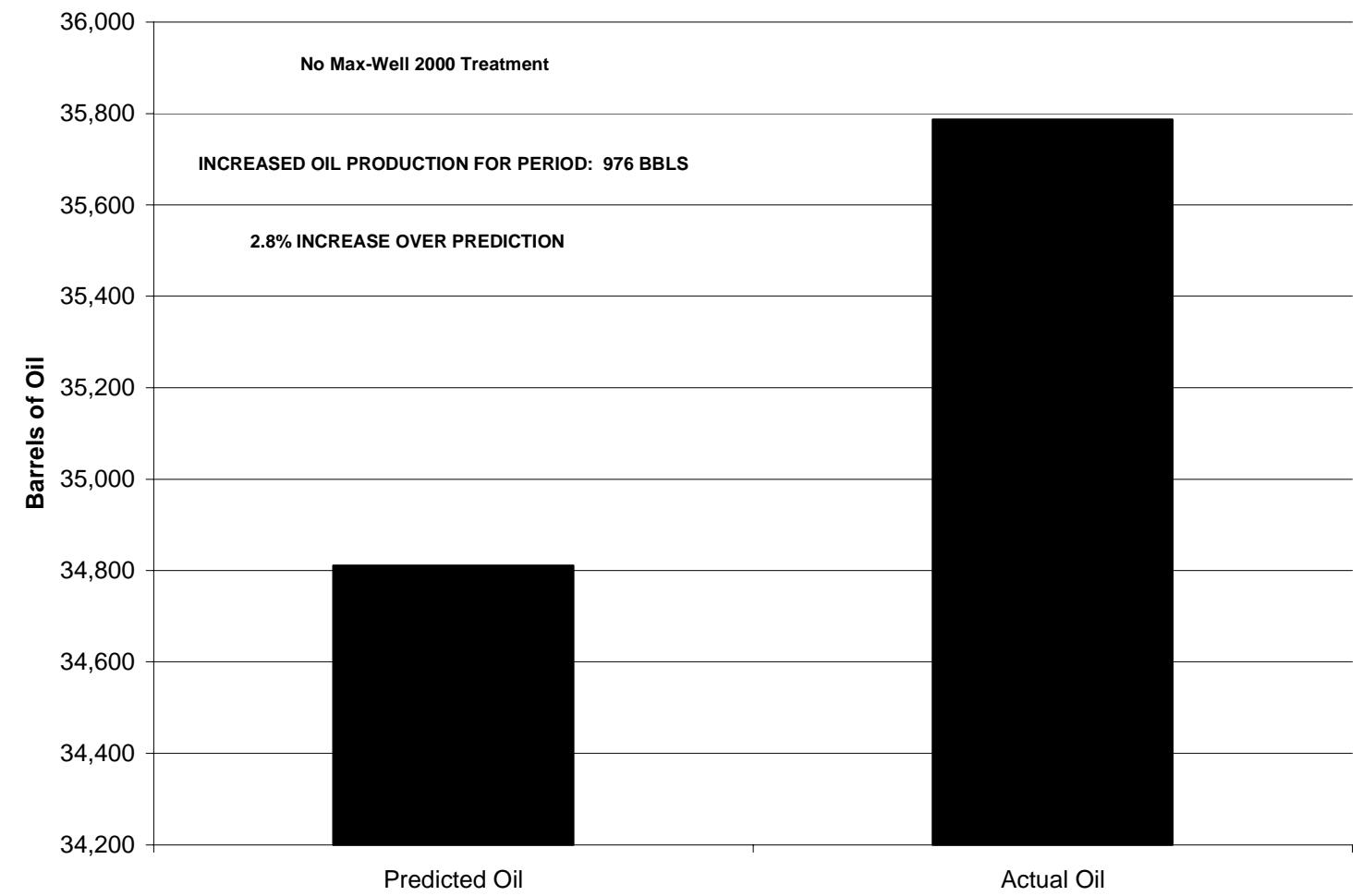

Figure 11. Combined production for seven control wells, Mar. 20 - Sept. 30, 2001.

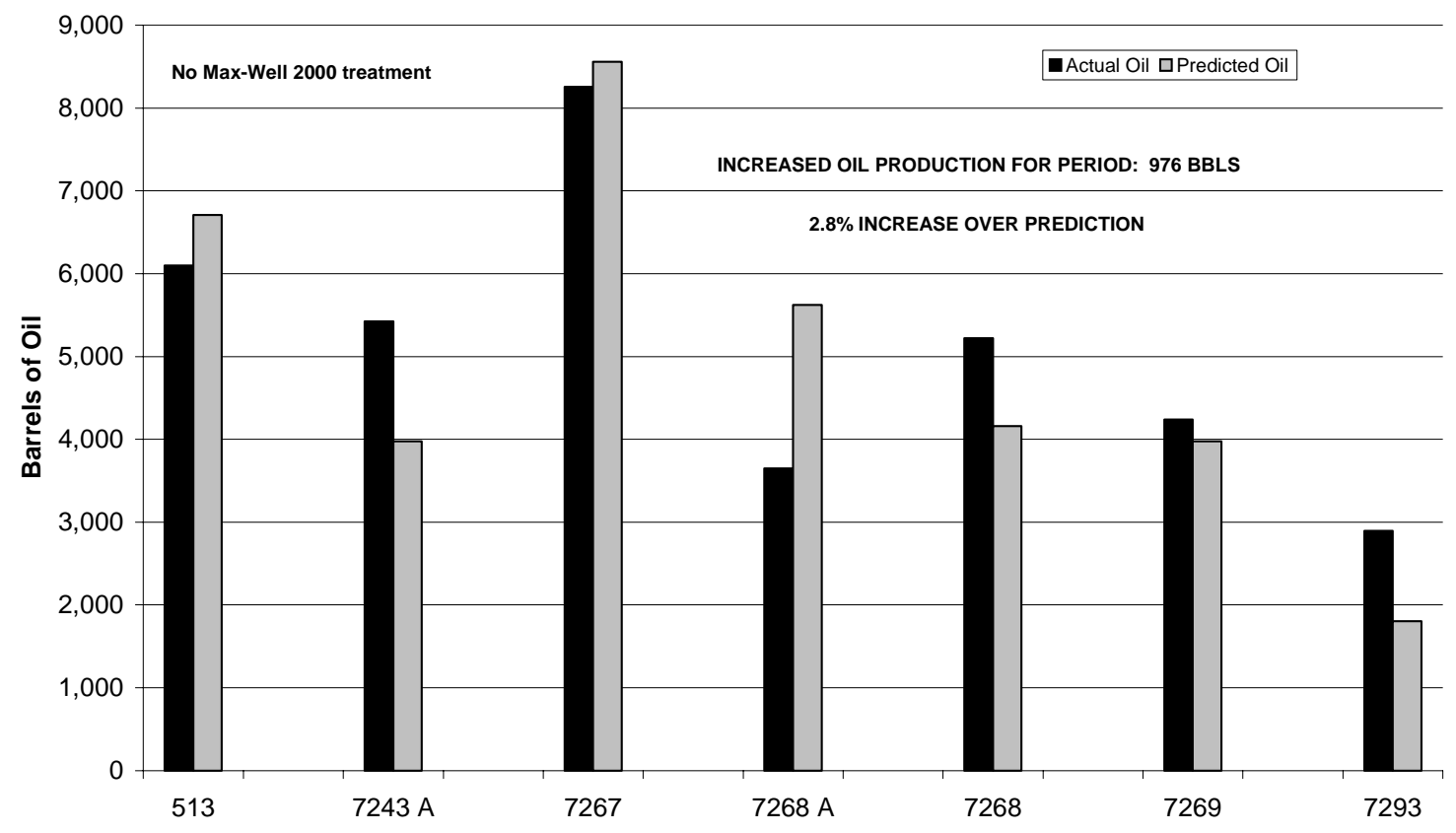

Figure 12. Control well production Mar. 20 - Sept. 30, 2001. 
A second field test was conducted with Aera Energy in the Belridge field. The objective was to use a different Max-Well nutrient product to reduce $\mathrm{H}_{2} \mathrm{~S}$ and improve the water/oil ratio (WOR) in three ways: suppress growth of sulfate reducing bacteria while increasing the population of denitrifying bacteria; reduce iron sulfide in the near-wellbore area to free up production pathways; and stimulate indigenous bacteria to produce oil-releasing byproducts. The treatments were started September 14, 2001. The field was treated with monthly batch treatments, rather than on a continual basis. In some cases the $\mathrm{H}_{2} \mathrm{~S}$ increased, which indicates the treatment is breaking up the iron sulfides and freeing up the production pathways. Results are shown in Figures 13-42. The data shown are the daily averages for each month. Data collected since January 1 has not yet been compiled, and will be included in the next report.

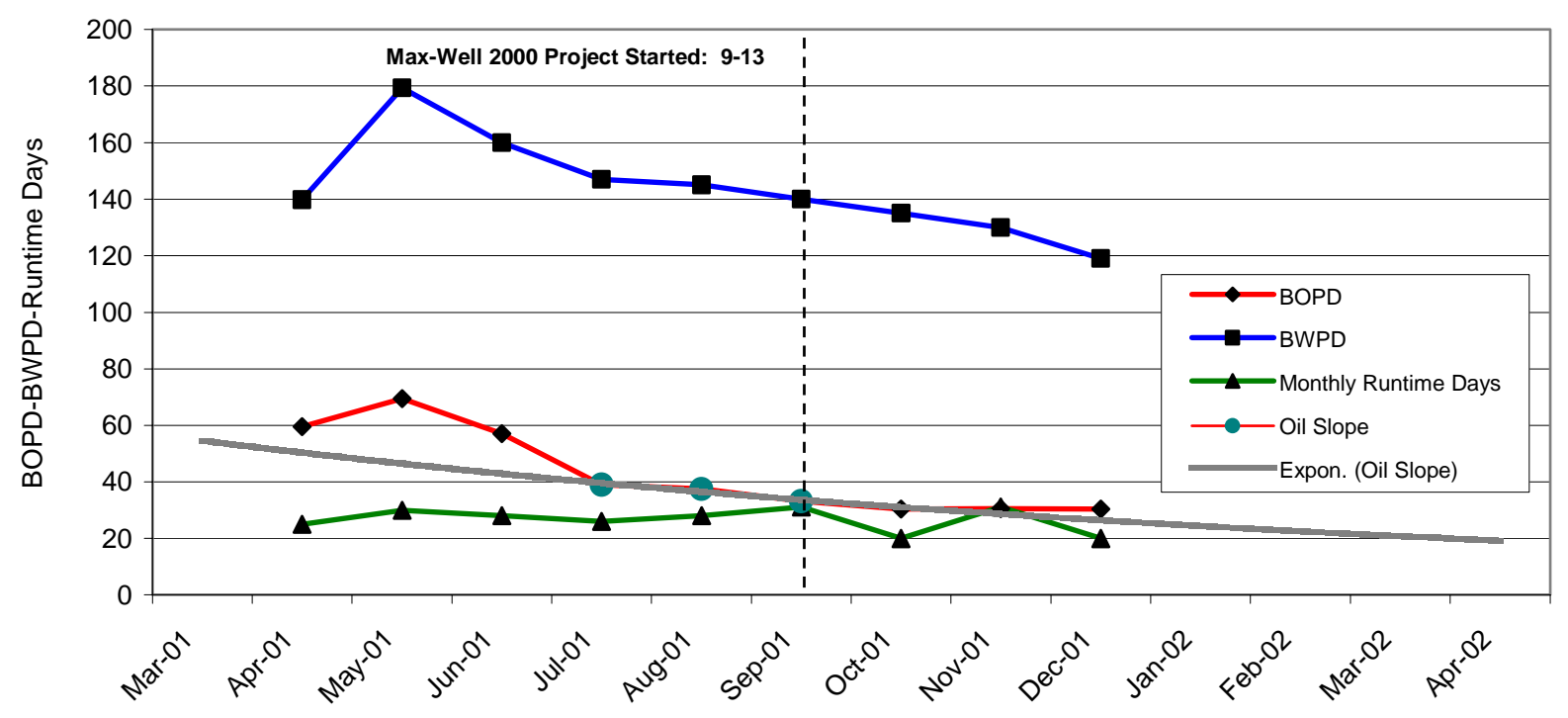

Figure 13. Belridge control well 7284A.

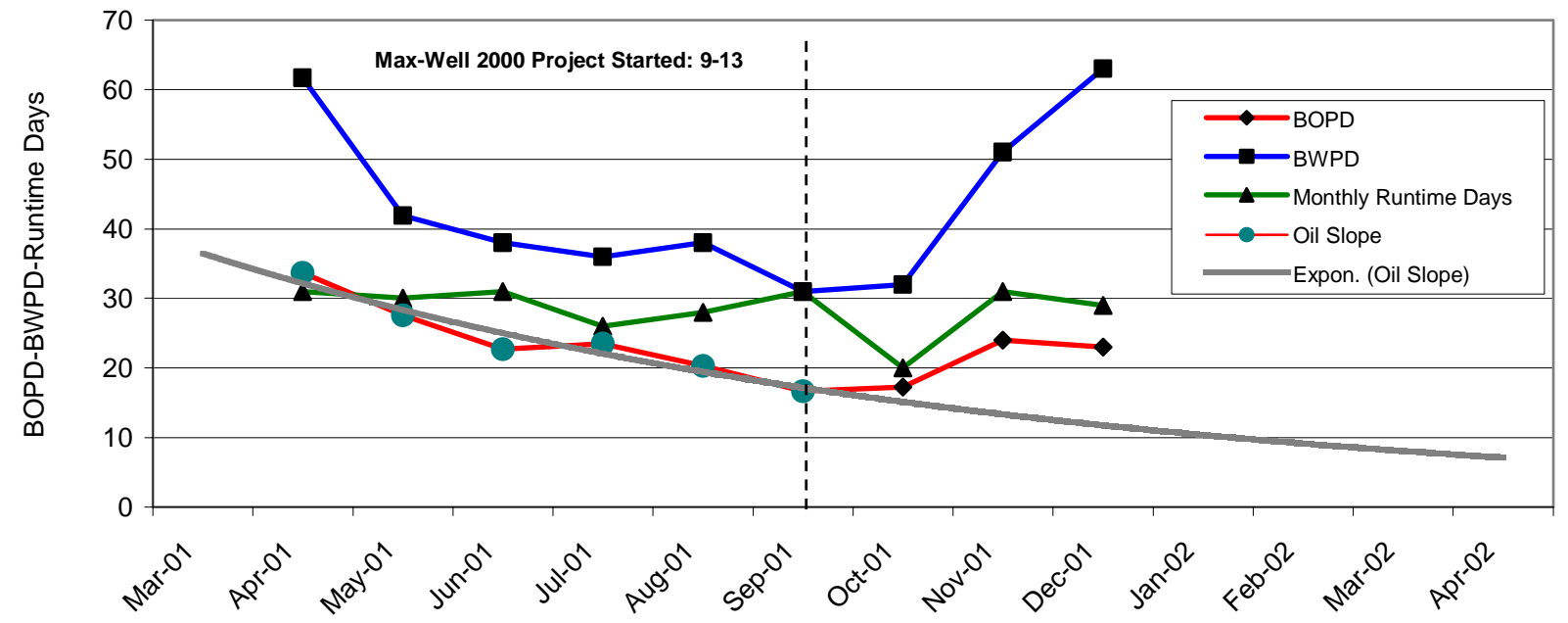

Figure 14. Belridge control well 7287A. 


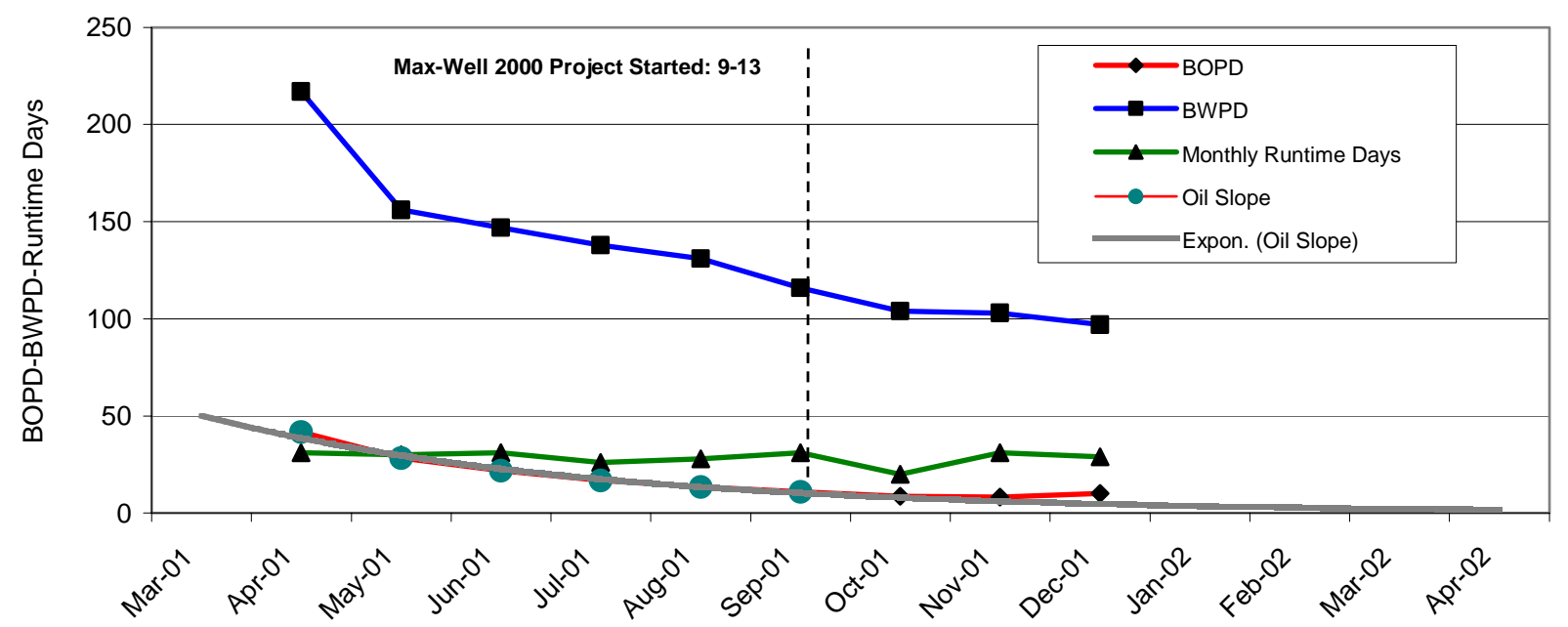

Figure 15. Belridge control well 7307A.

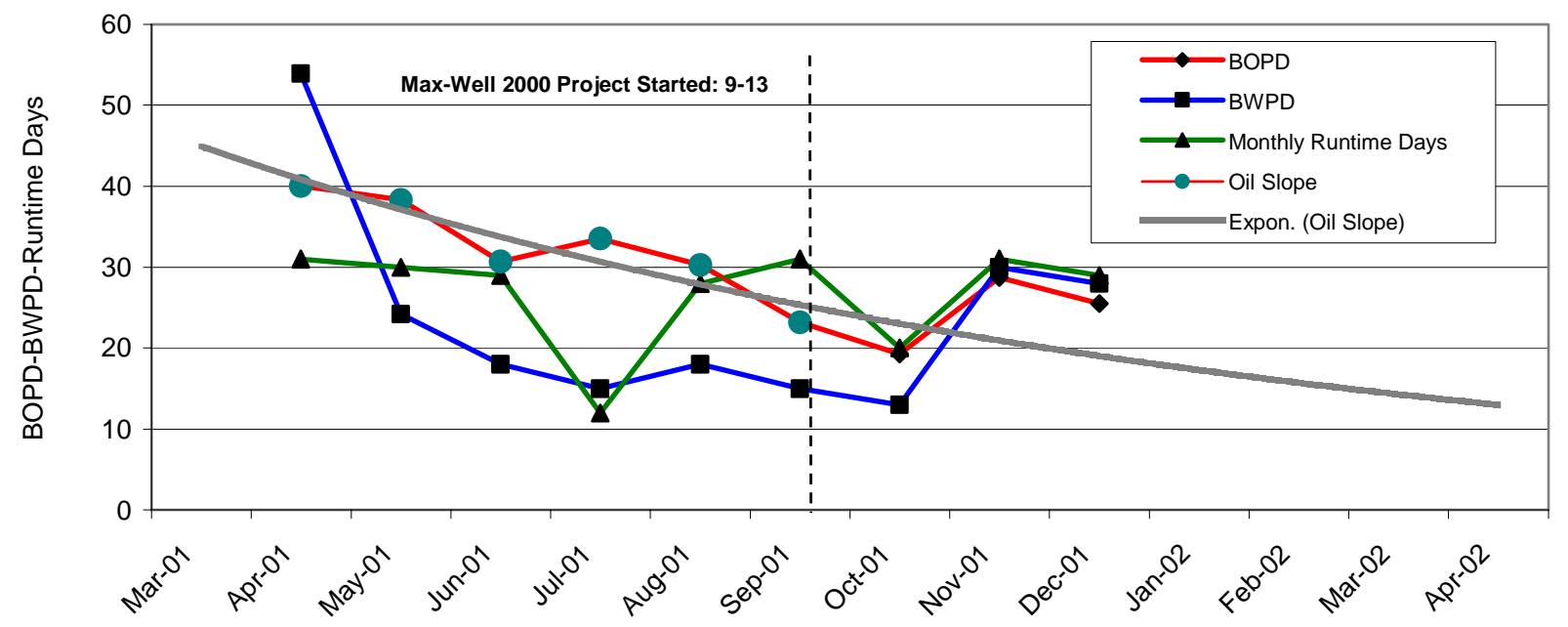

Figure 16. Belridge control well 7313. 


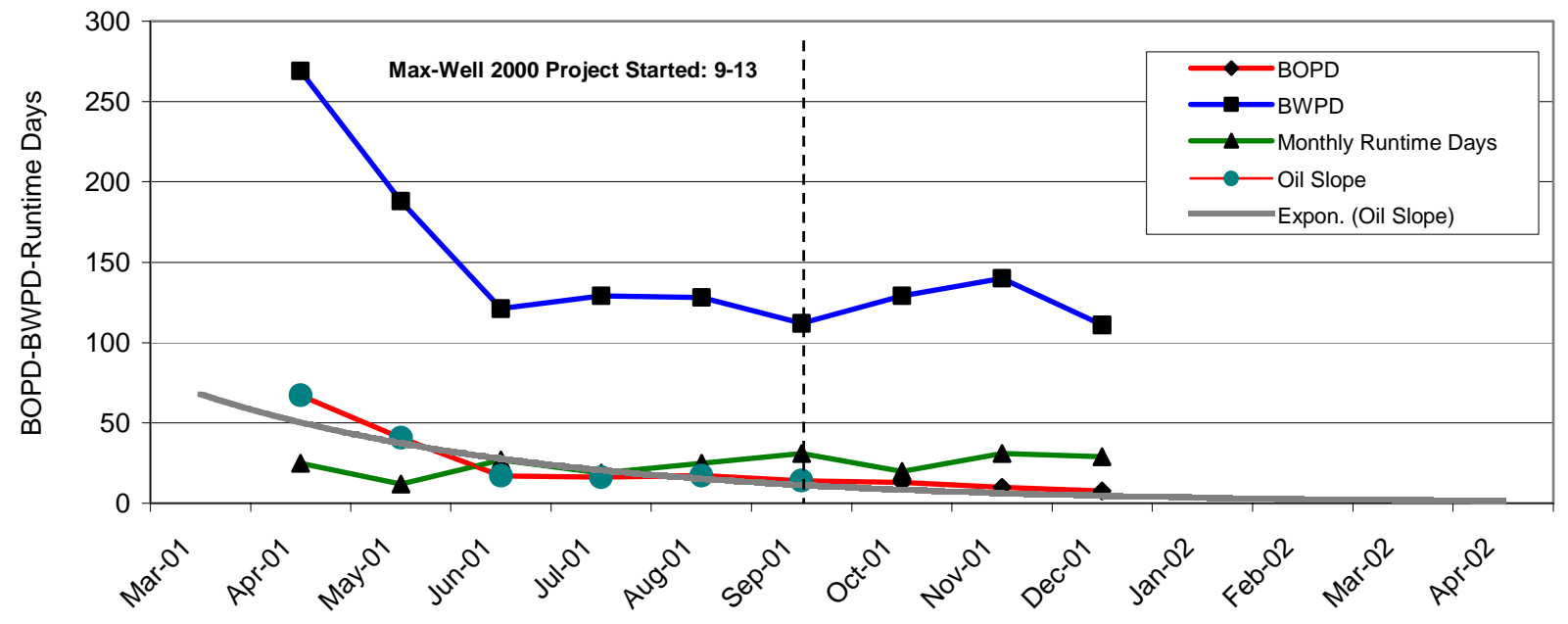

Figure 17. Belridge control well 7329.

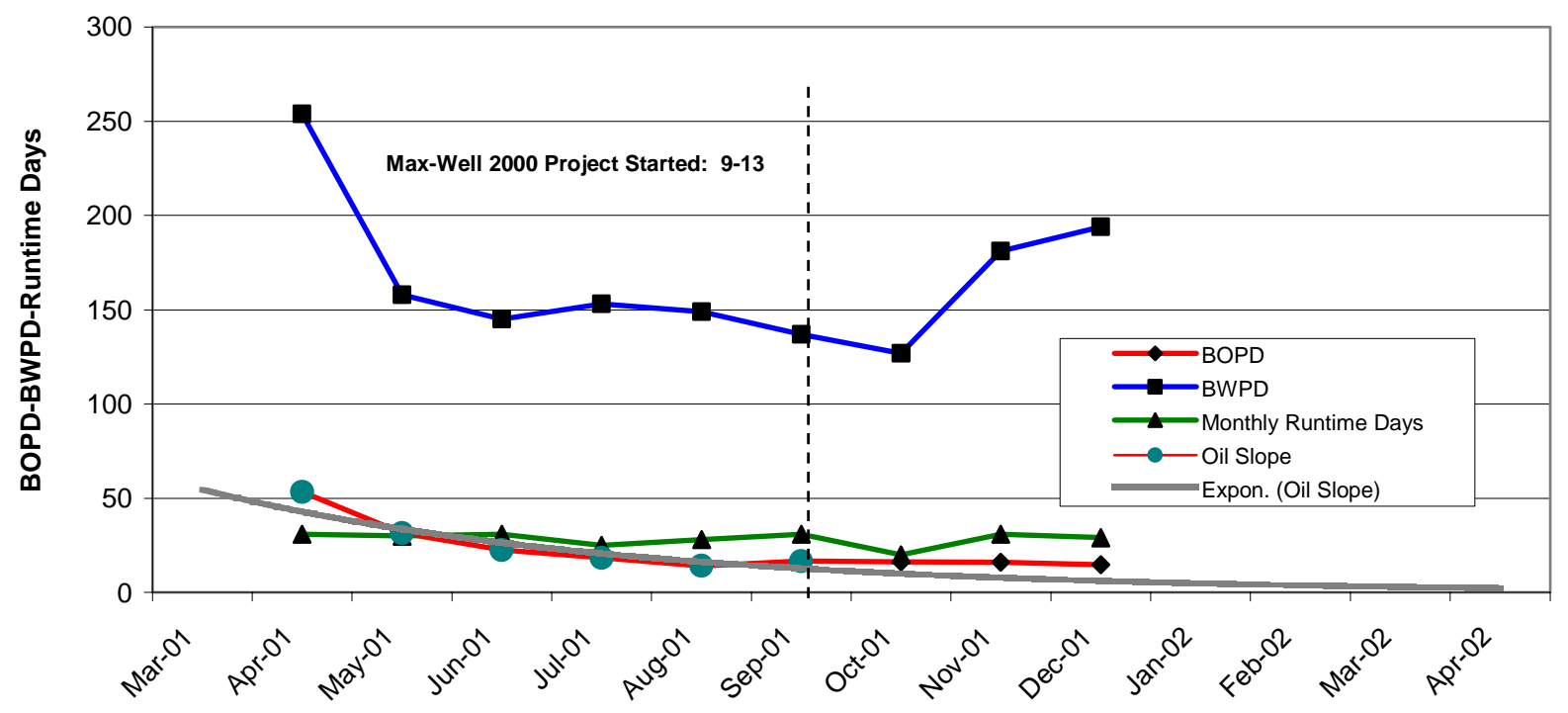

Figure 18. Belridge control well 7355A. 


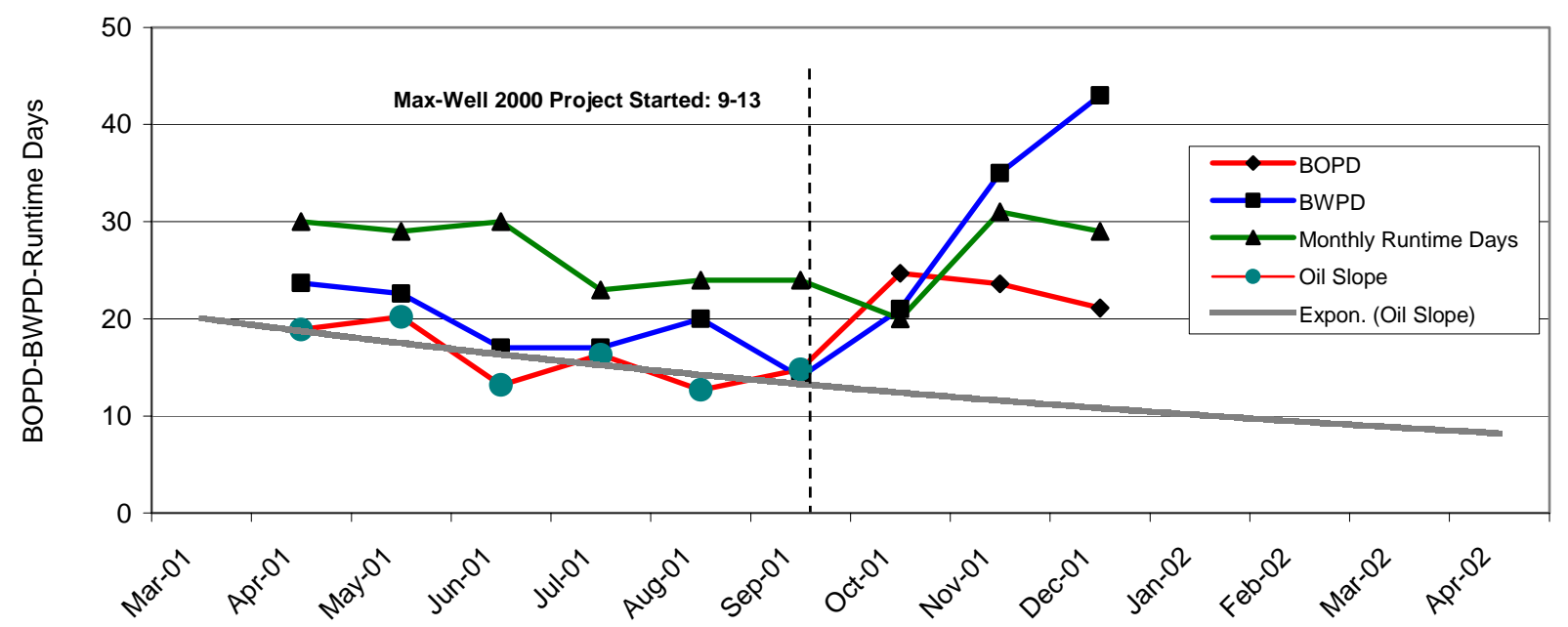

Figure 19. Belridge control well 7361B

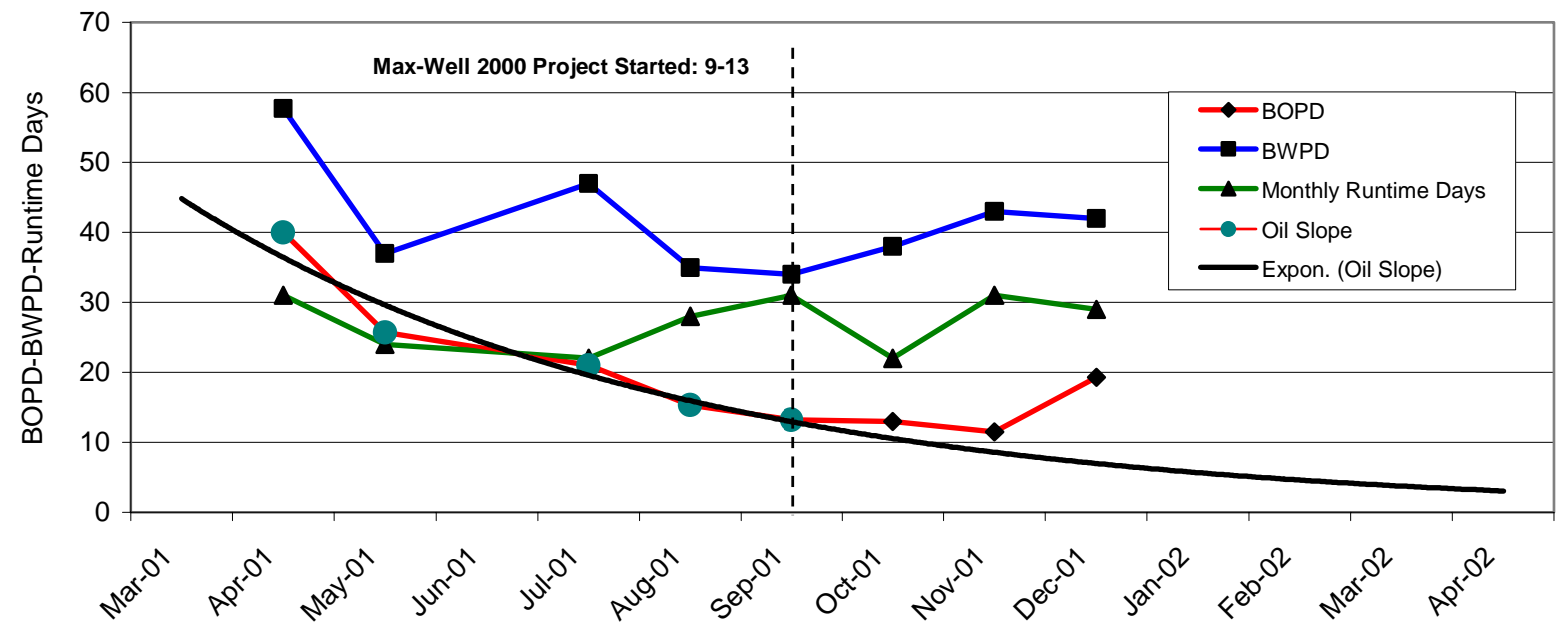

Figure 20. Belridge control well 7383. 


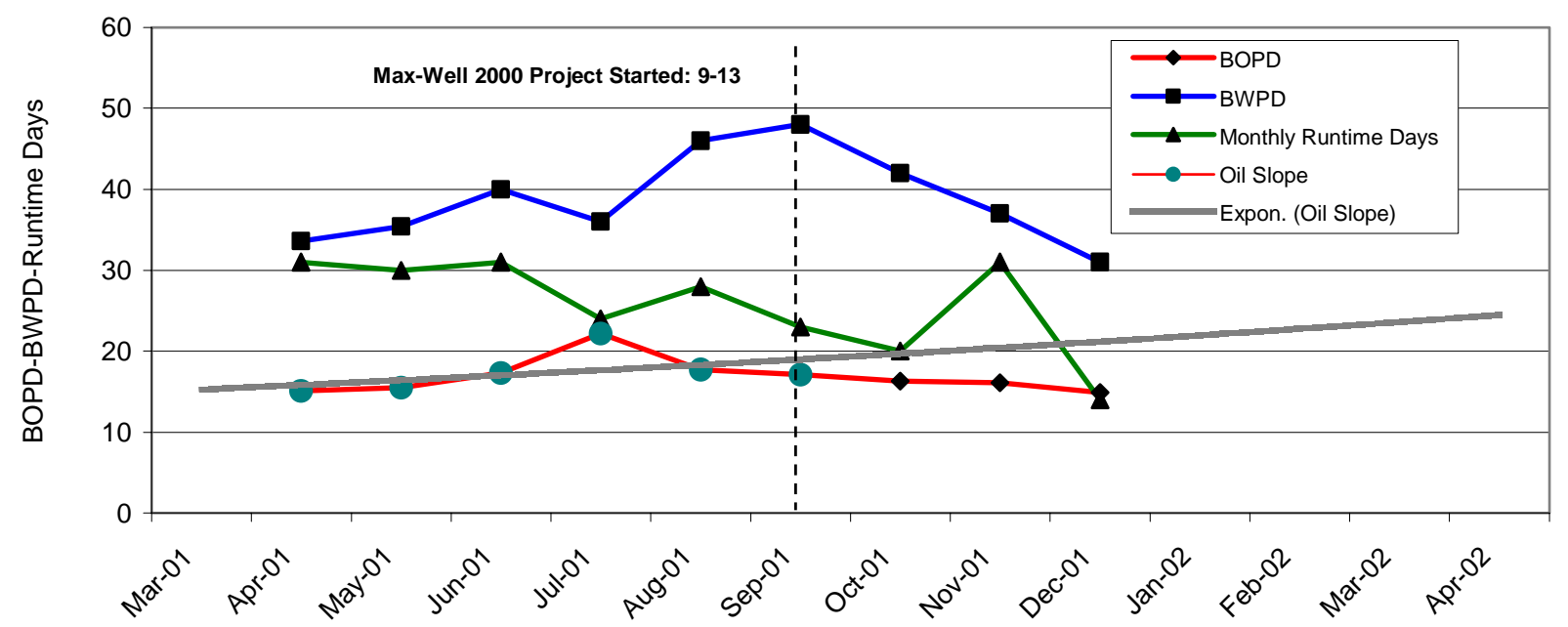

Figure 21. Belridge control well 7406.

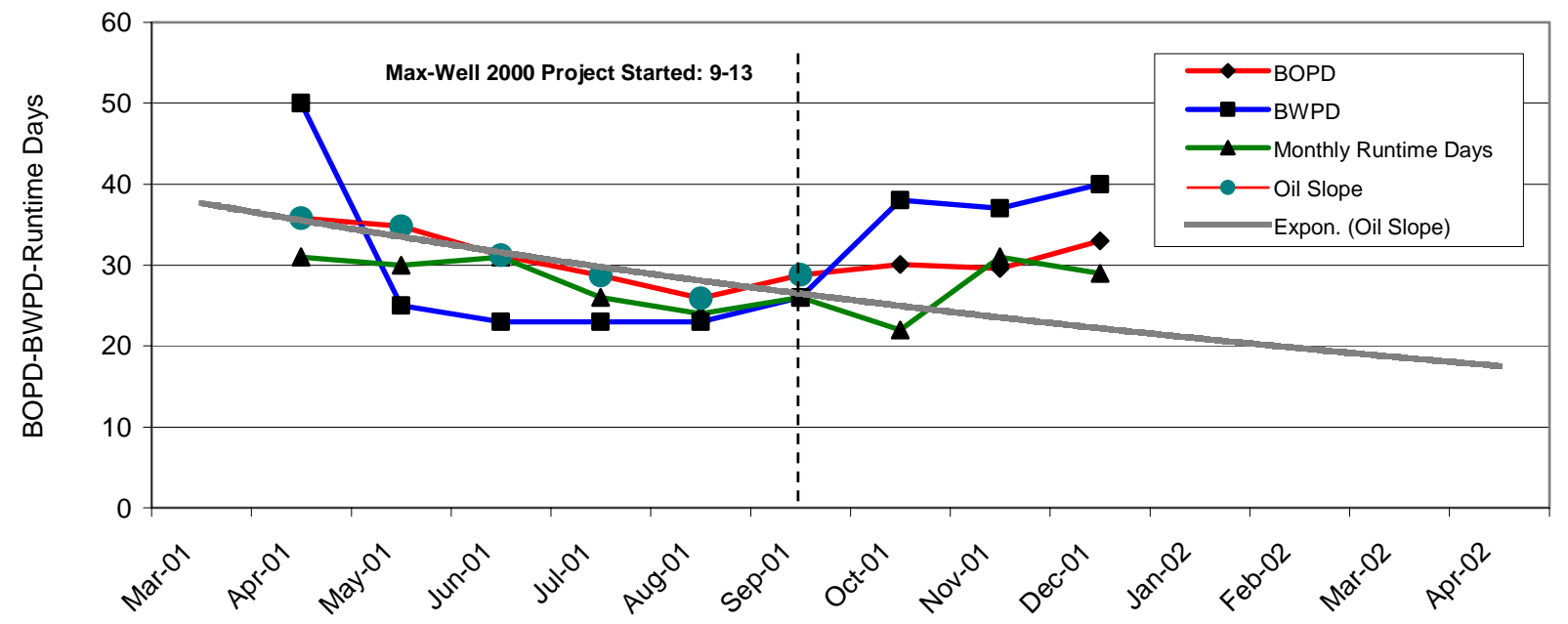

Figure 22. Belridge control well 7409. 


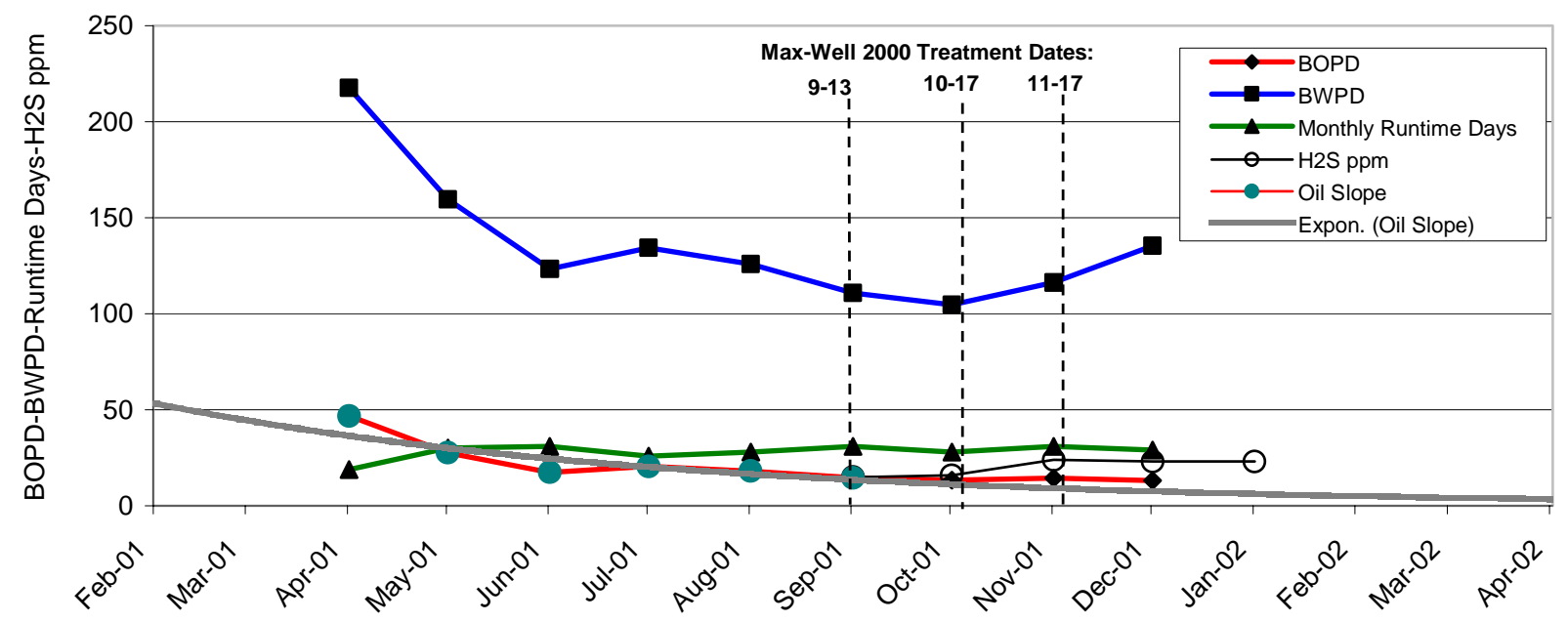

Figure 23. Belridge test well 7283.

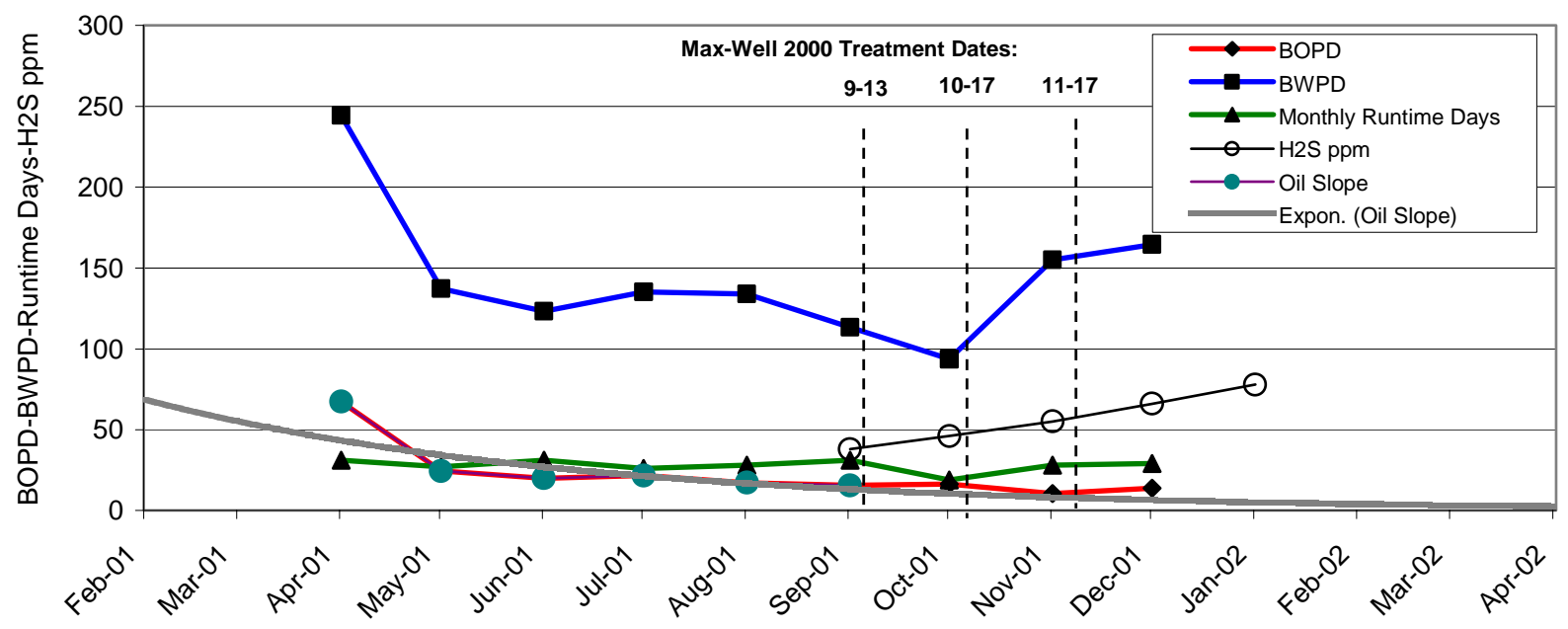

Figure 24. Belridge test well 7283A. 


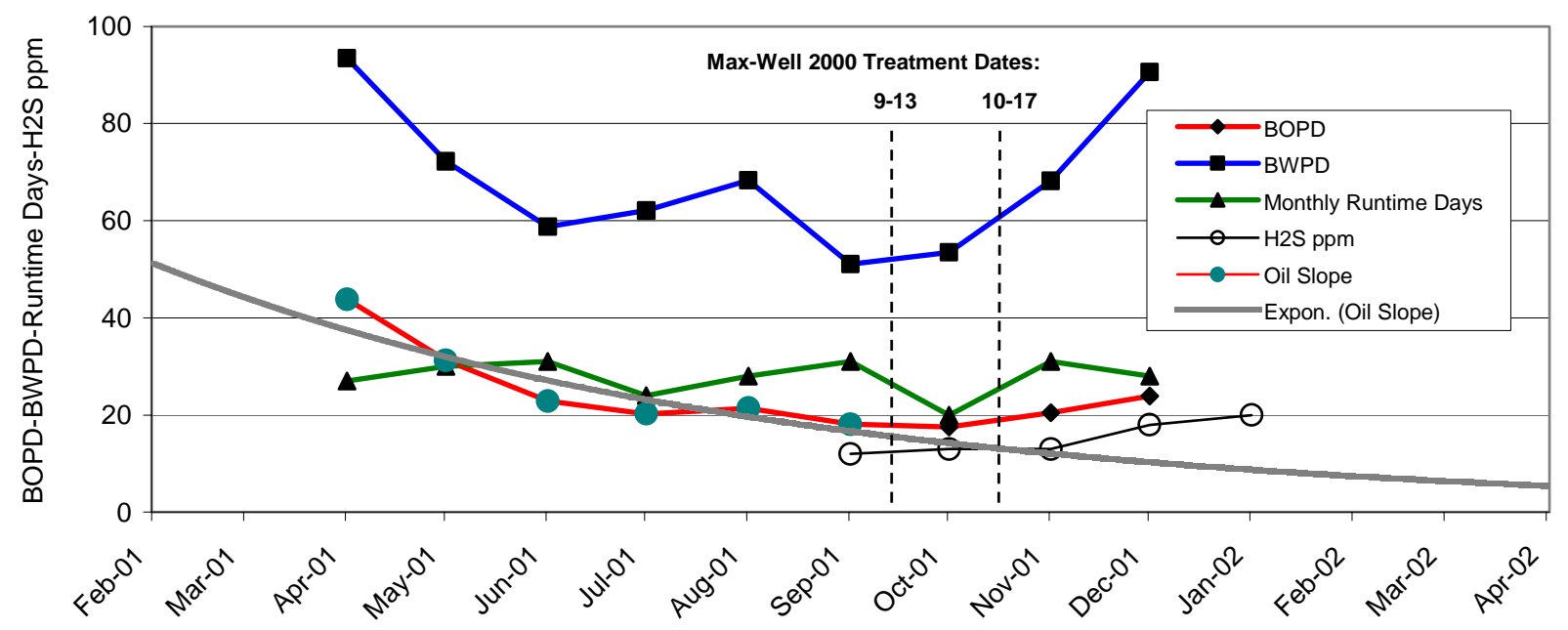

Figure 25. Belridge test well 7285A.

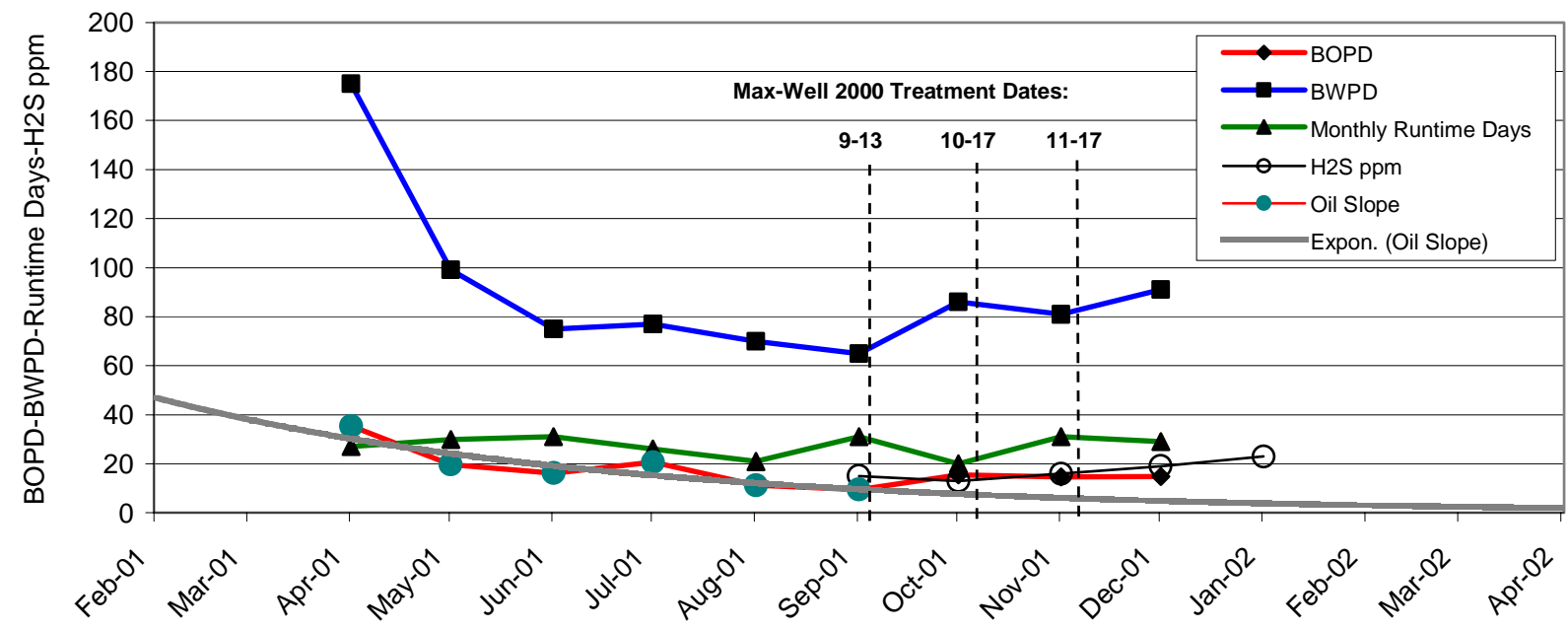

Figure 26. Belridge test well 7306A. 


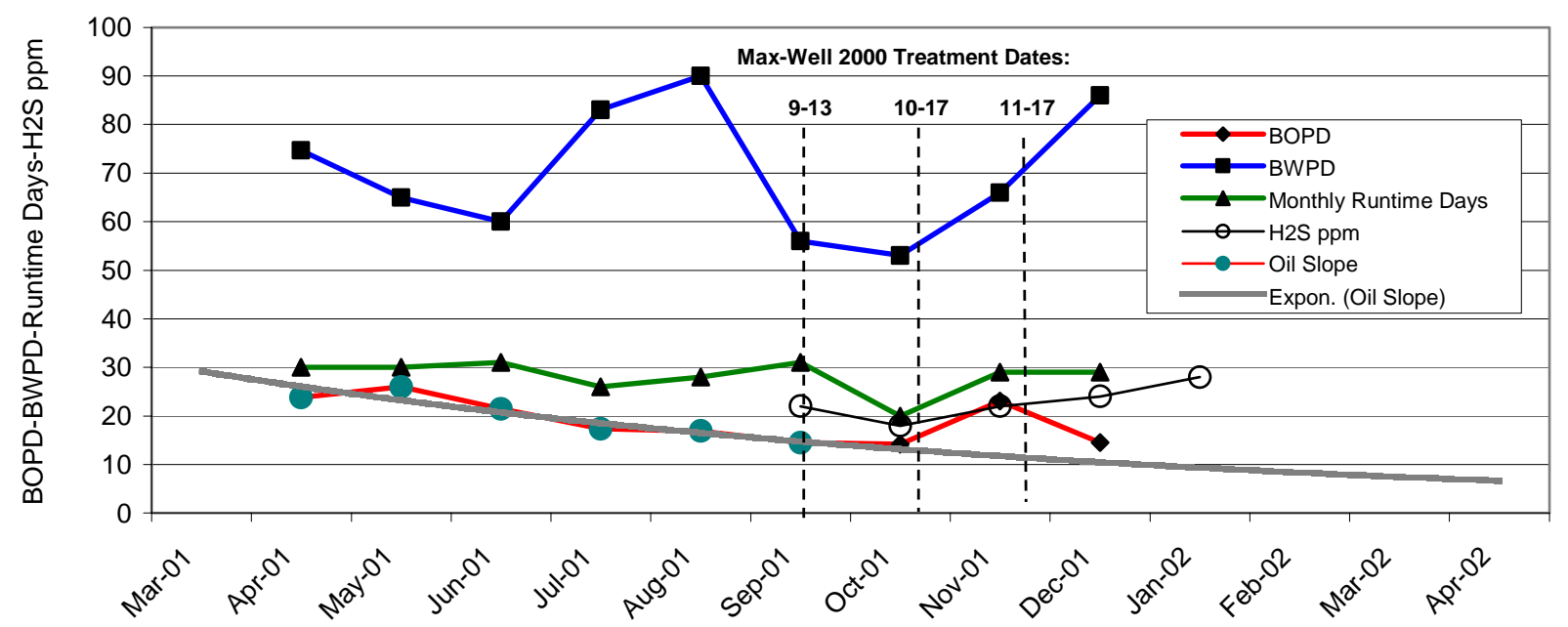

Figure 27. Belridge test well 7309A.

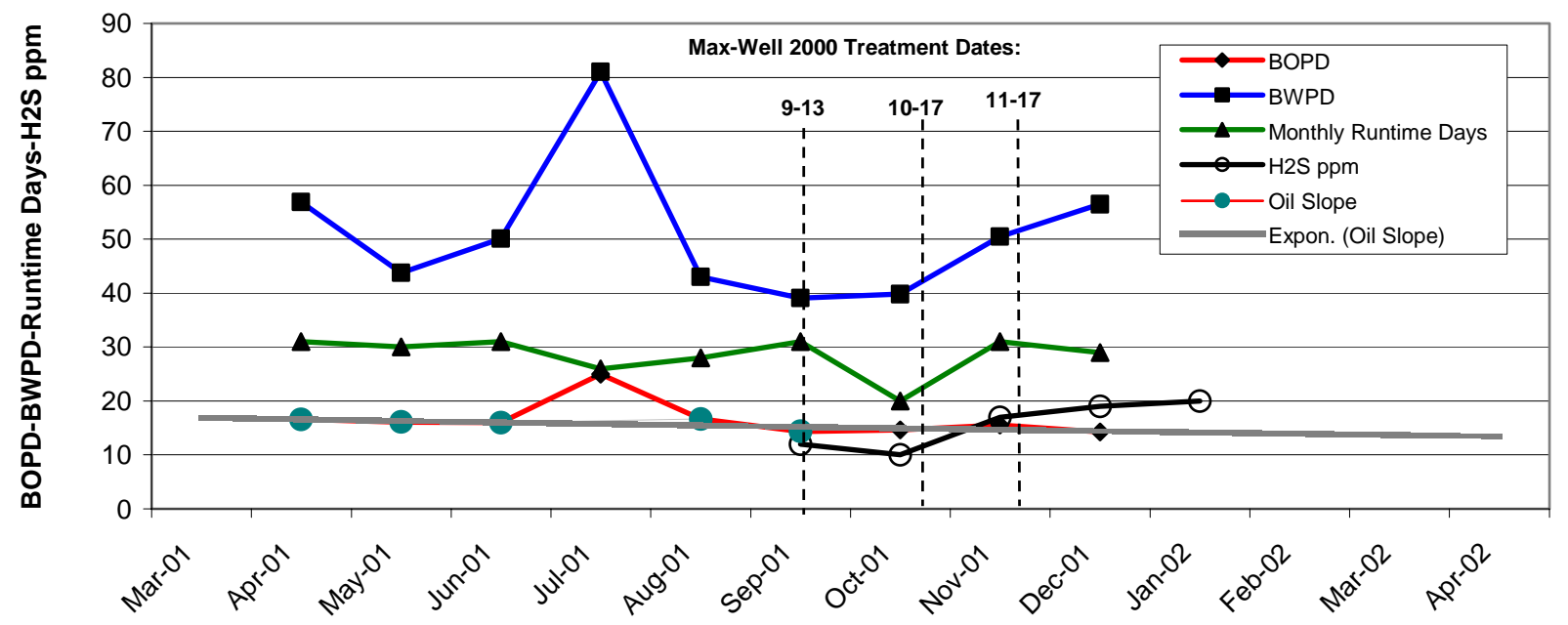

Figure 28. Belridge test well 7310A. 


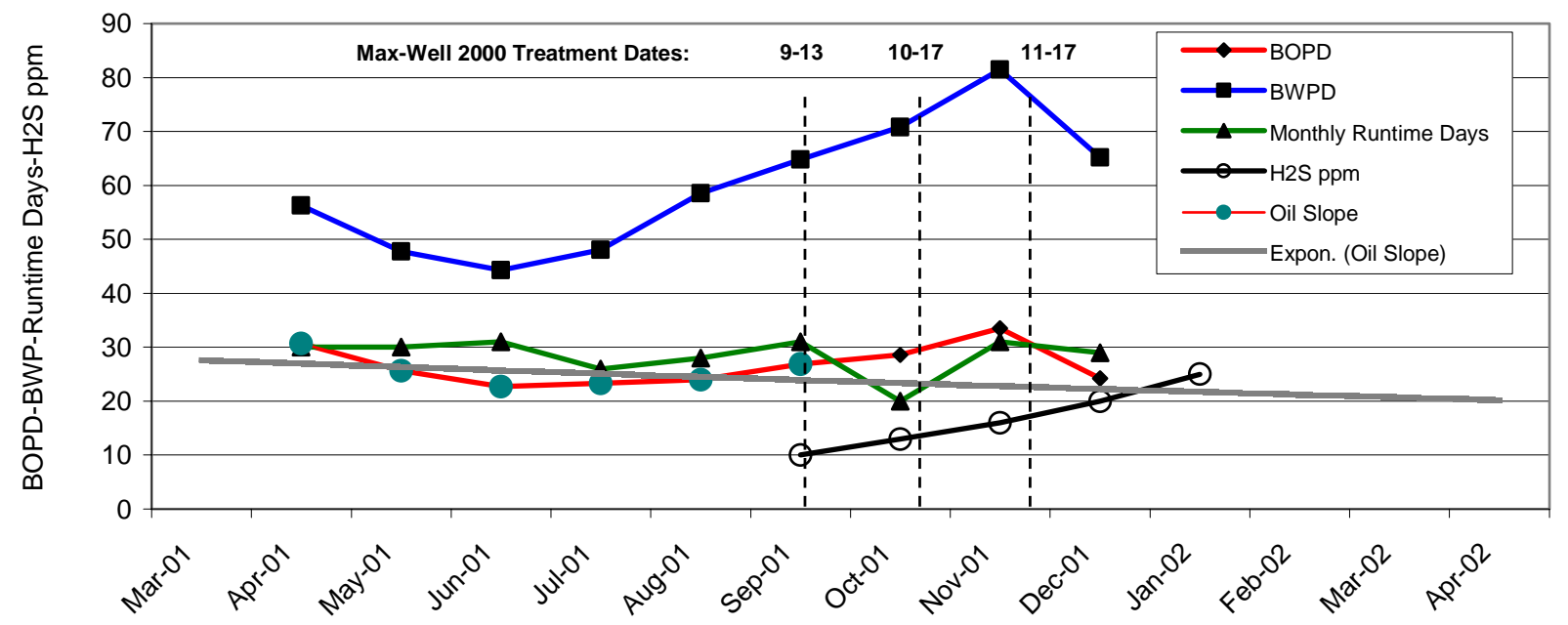

Figure 29. Belridge test well 7310B.

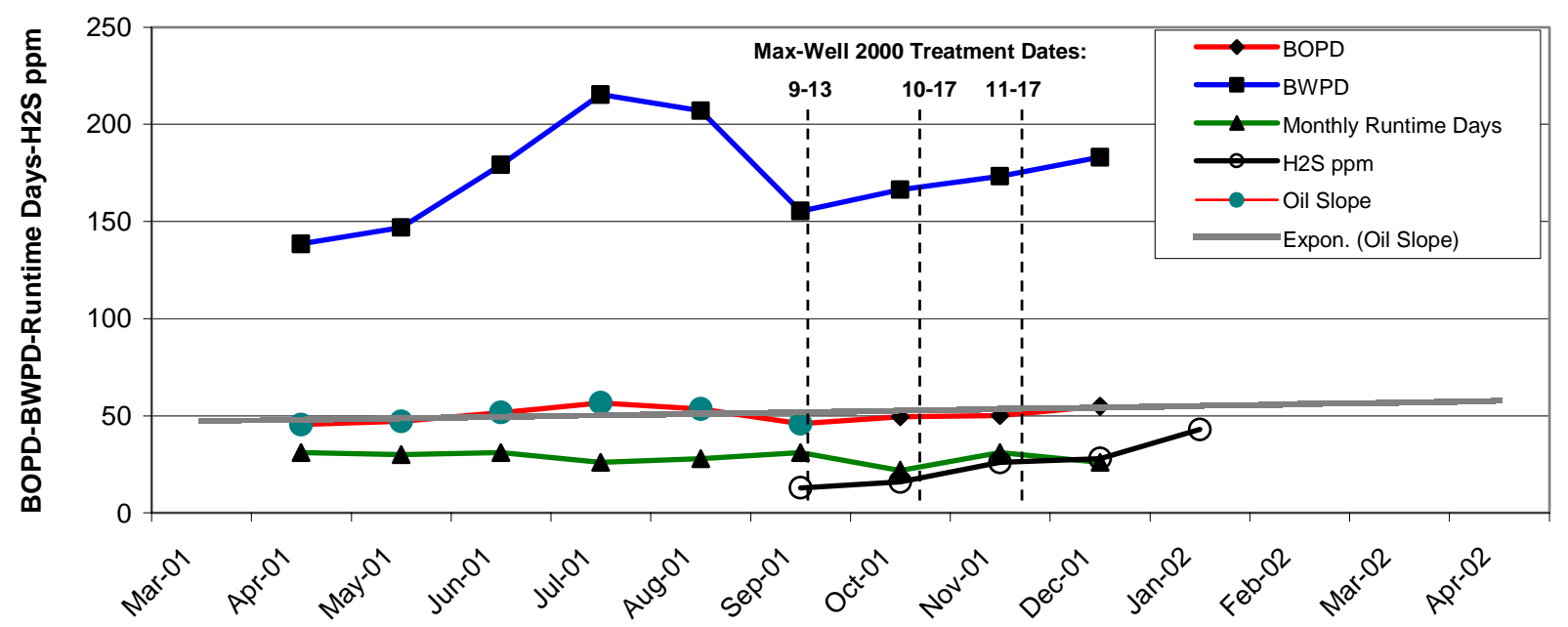

Figure 30. Belridge test well 7311A. 


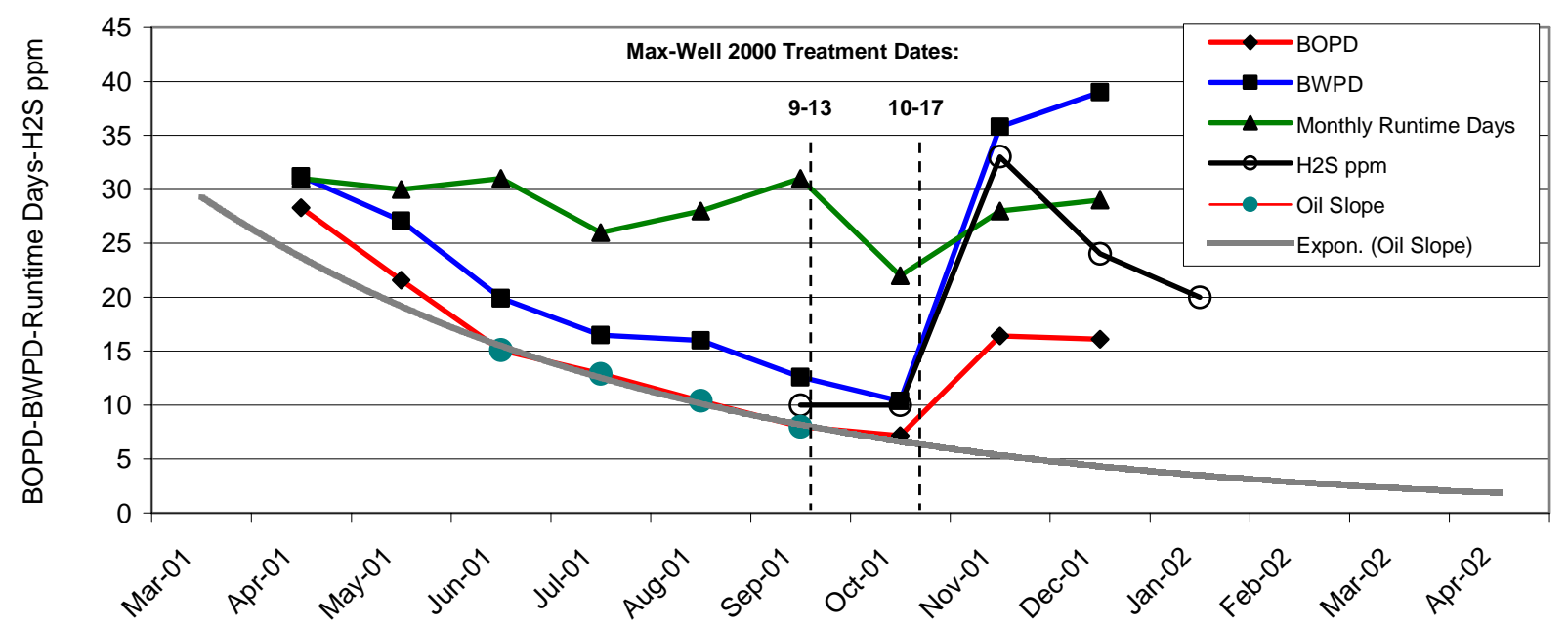

Figure 31. Belridge test well 7312.

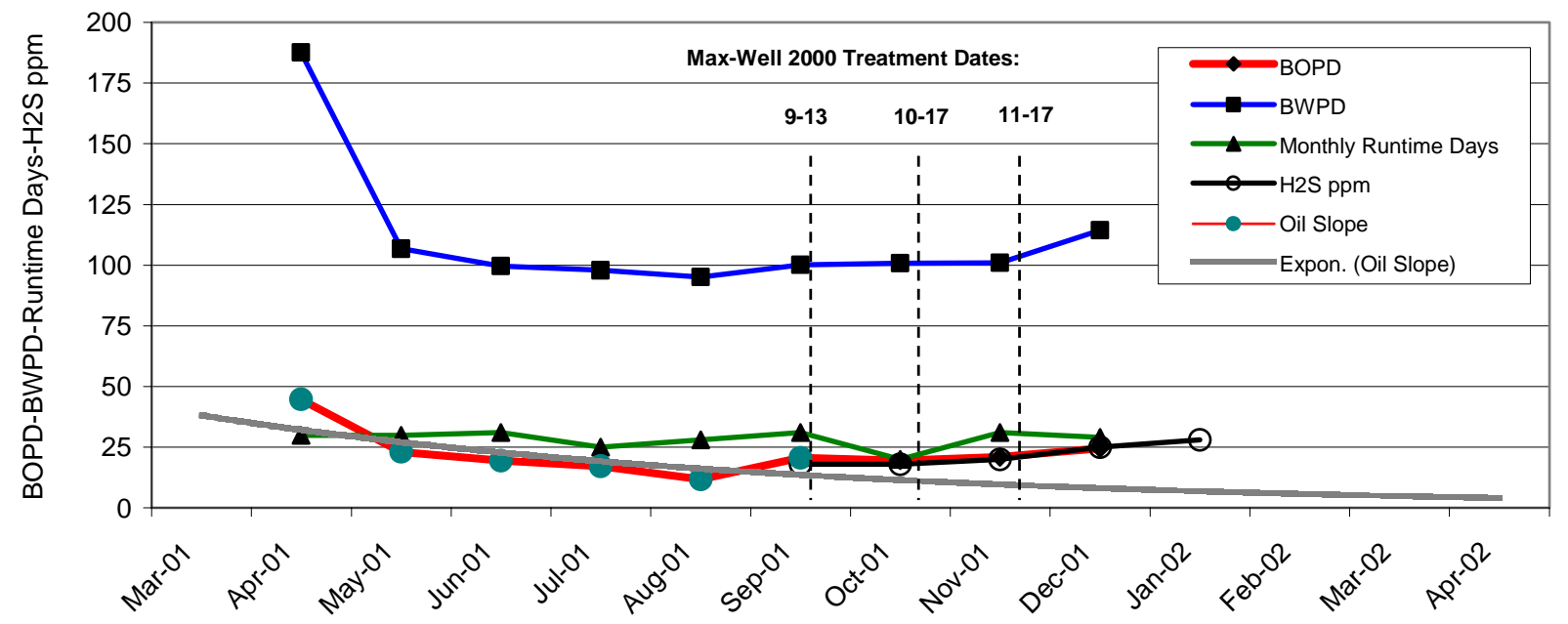

Figure 32. Belridge test well 7332A. 


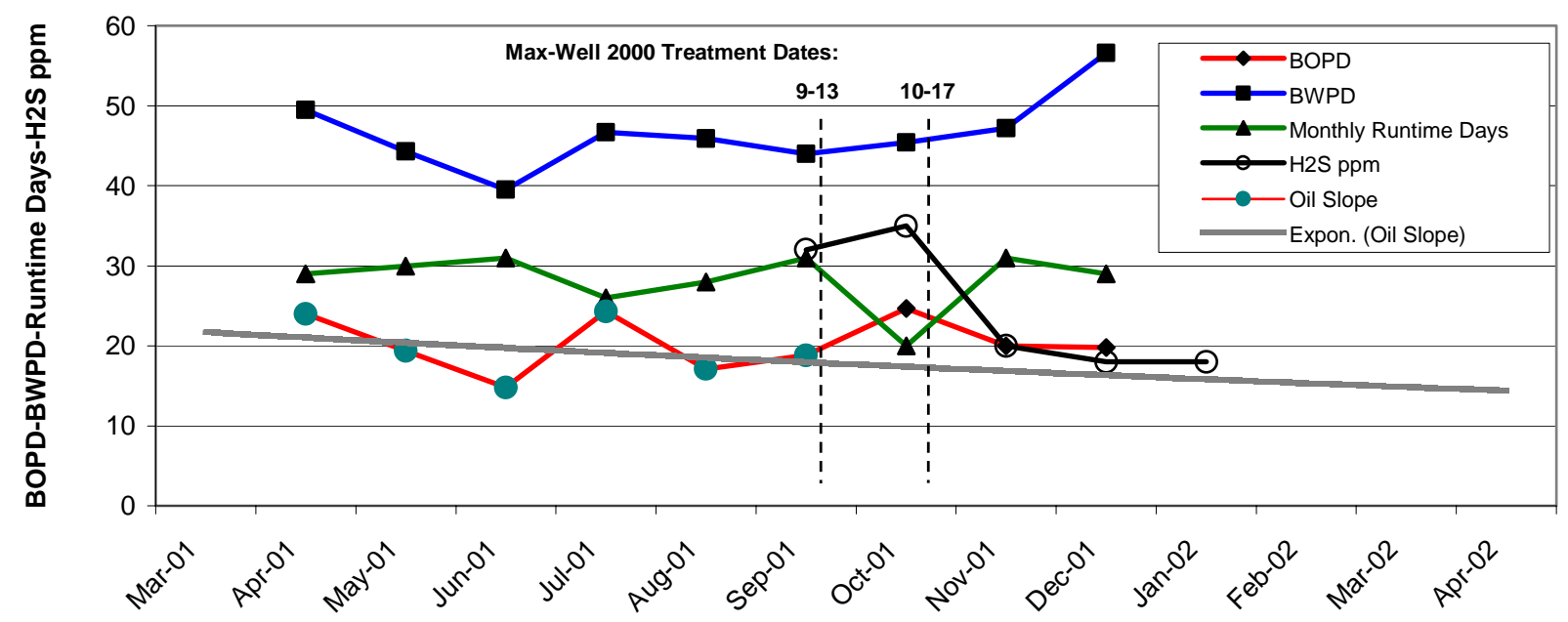

Figure 33. Belridge test well 7333.

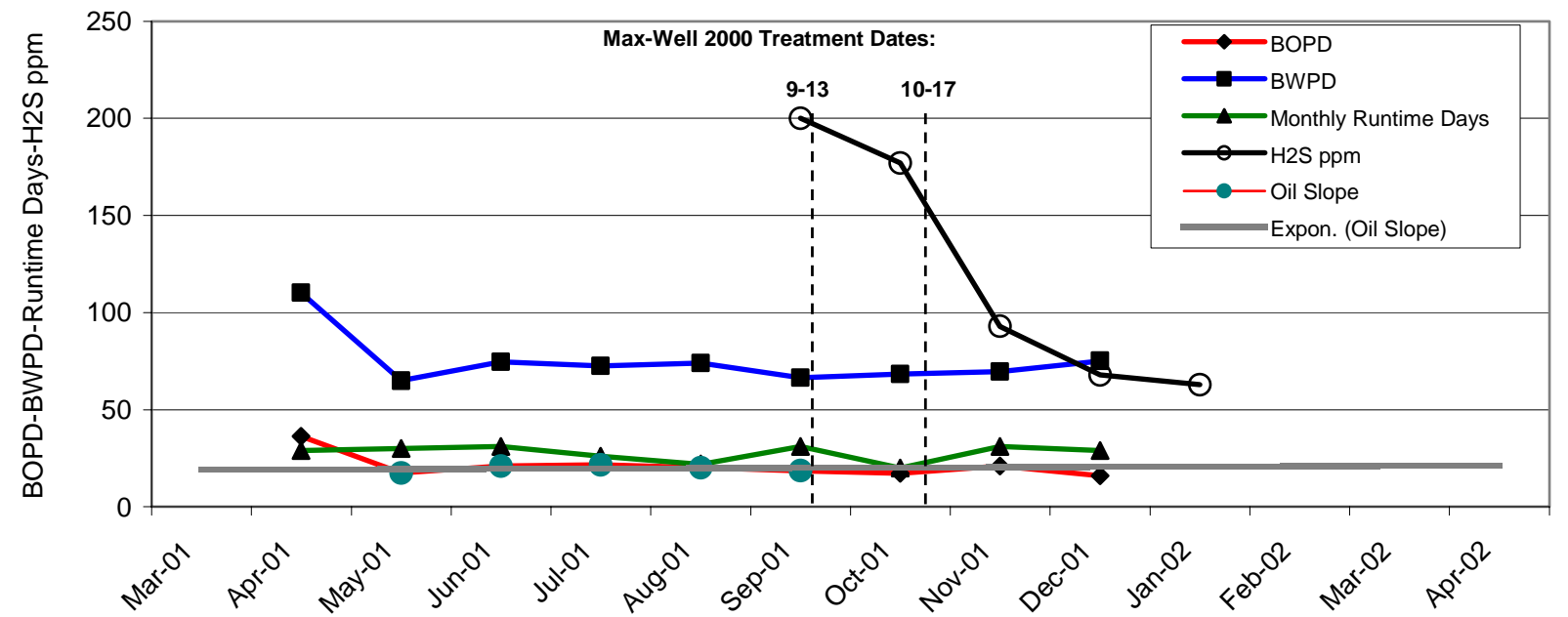

Figure 34. Belridge test well 7333B. 


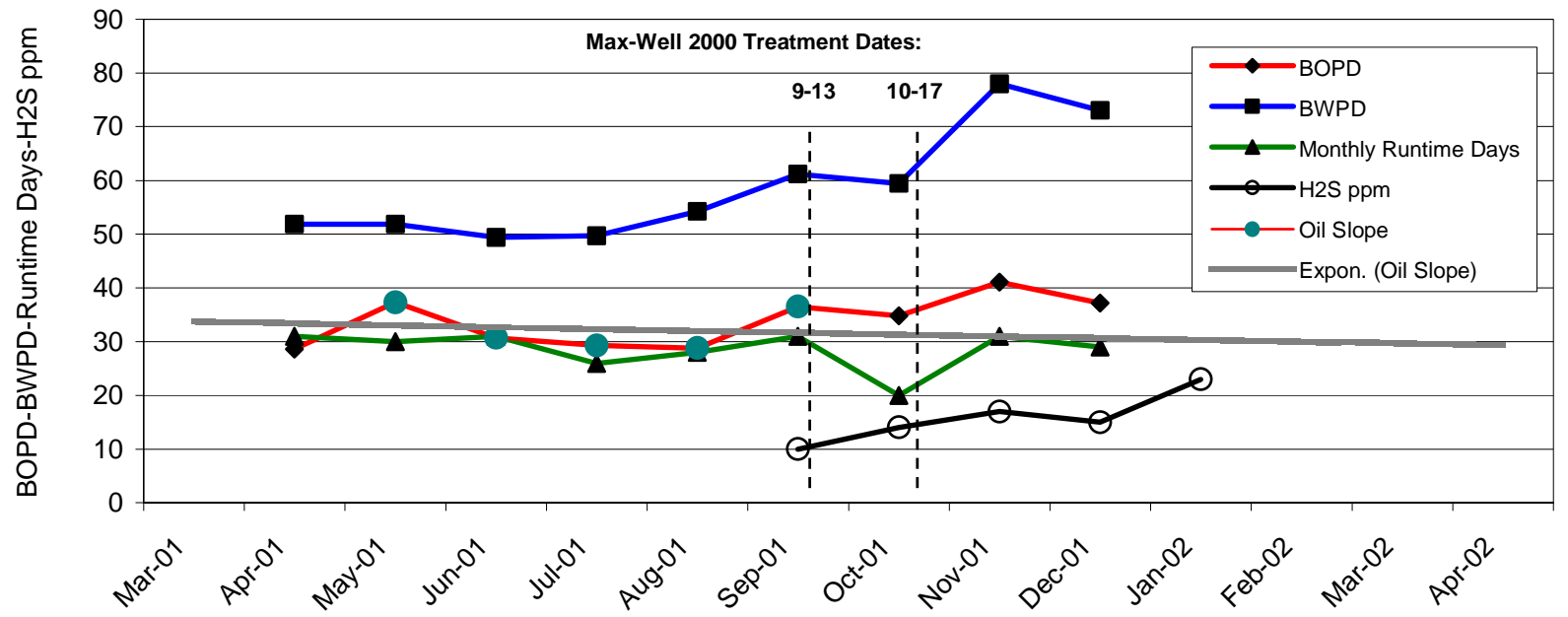

Figure 35. Belridge test well 7334A.

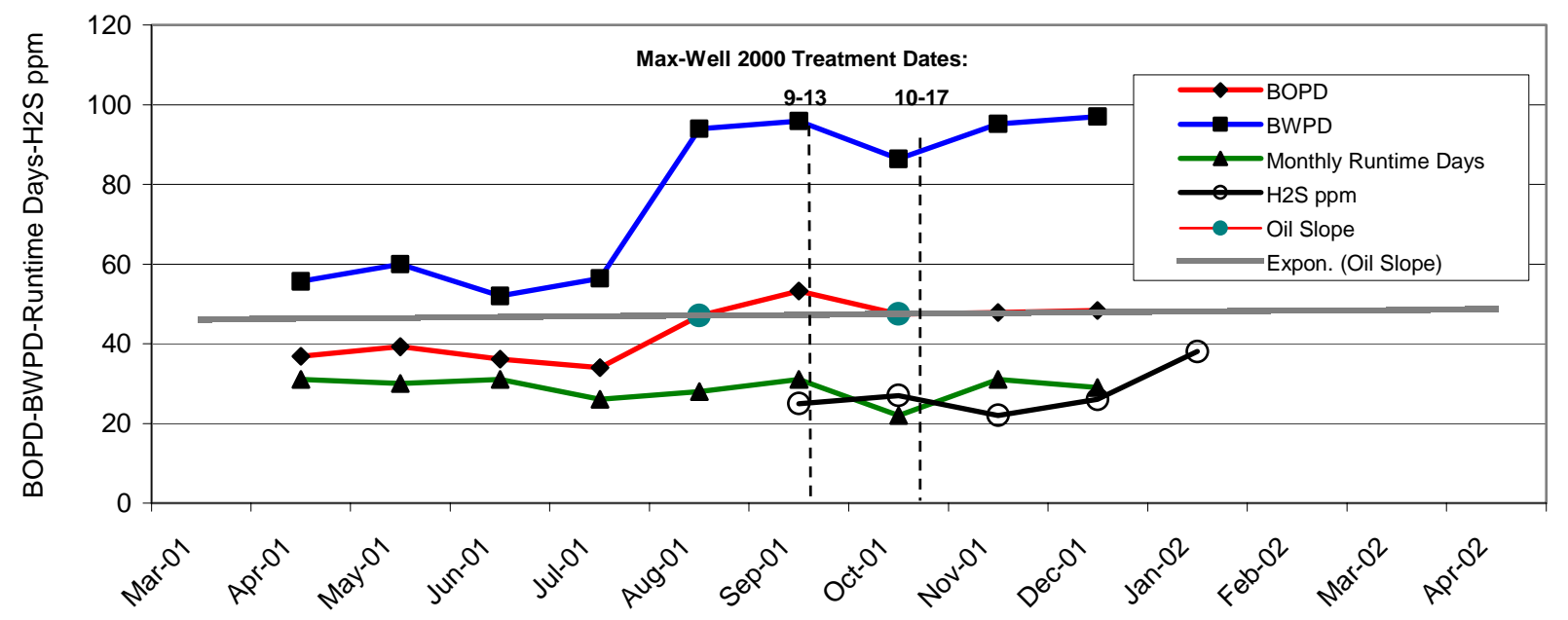

Figure 36. Belridge test well 7335. 


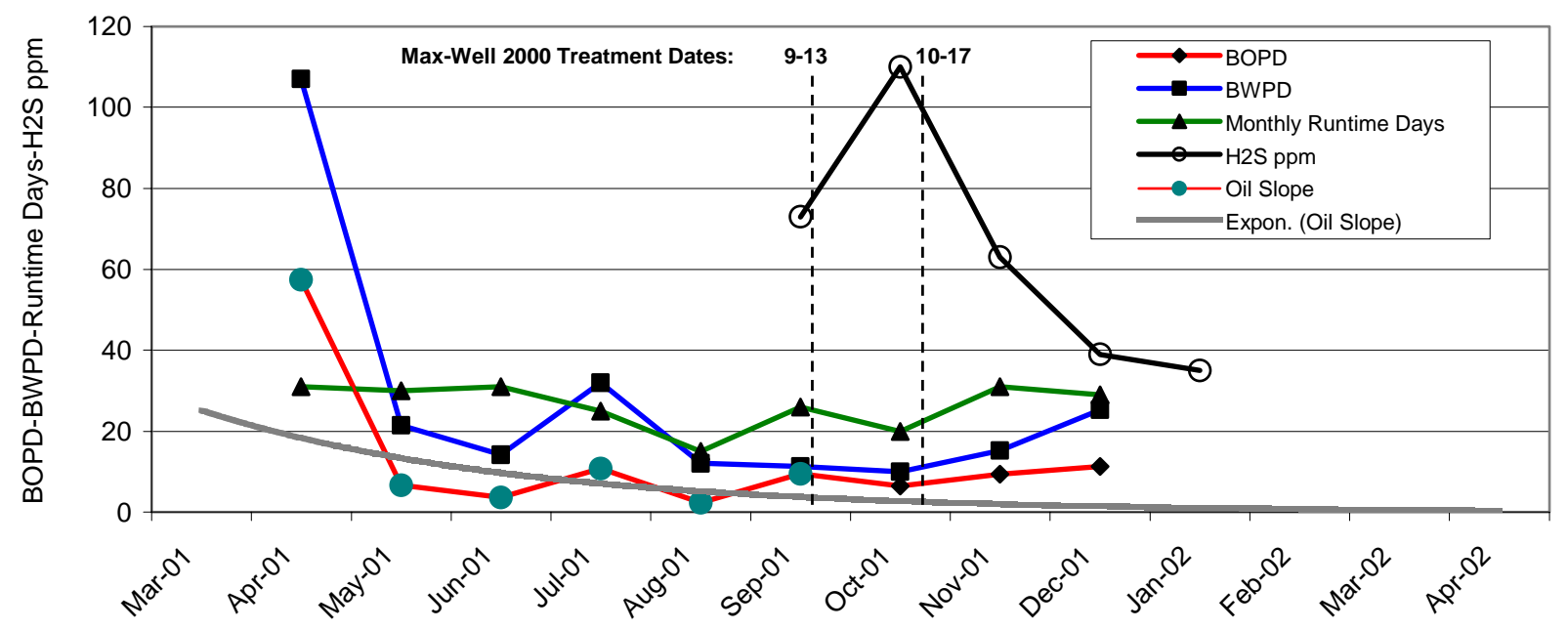

Figure 37. Belridge test well 7337.

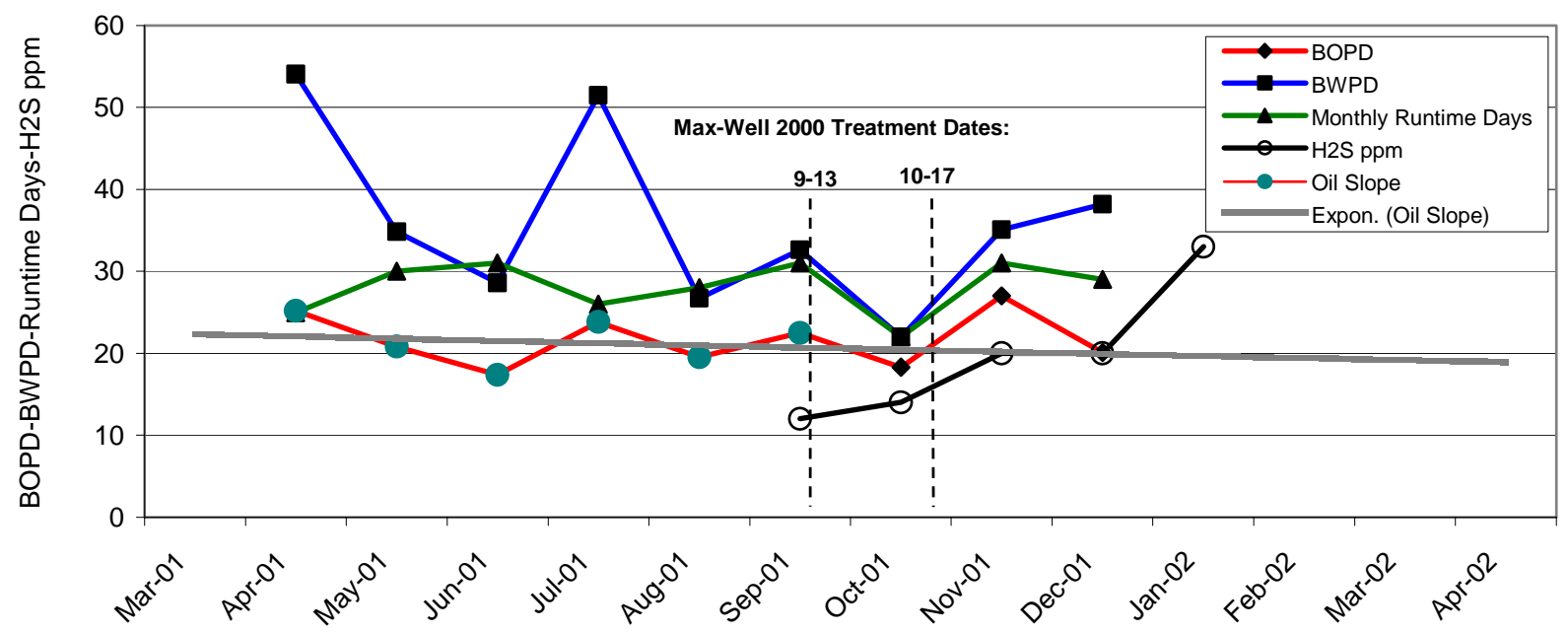

Figure 38. Belridge test well 7359A. 


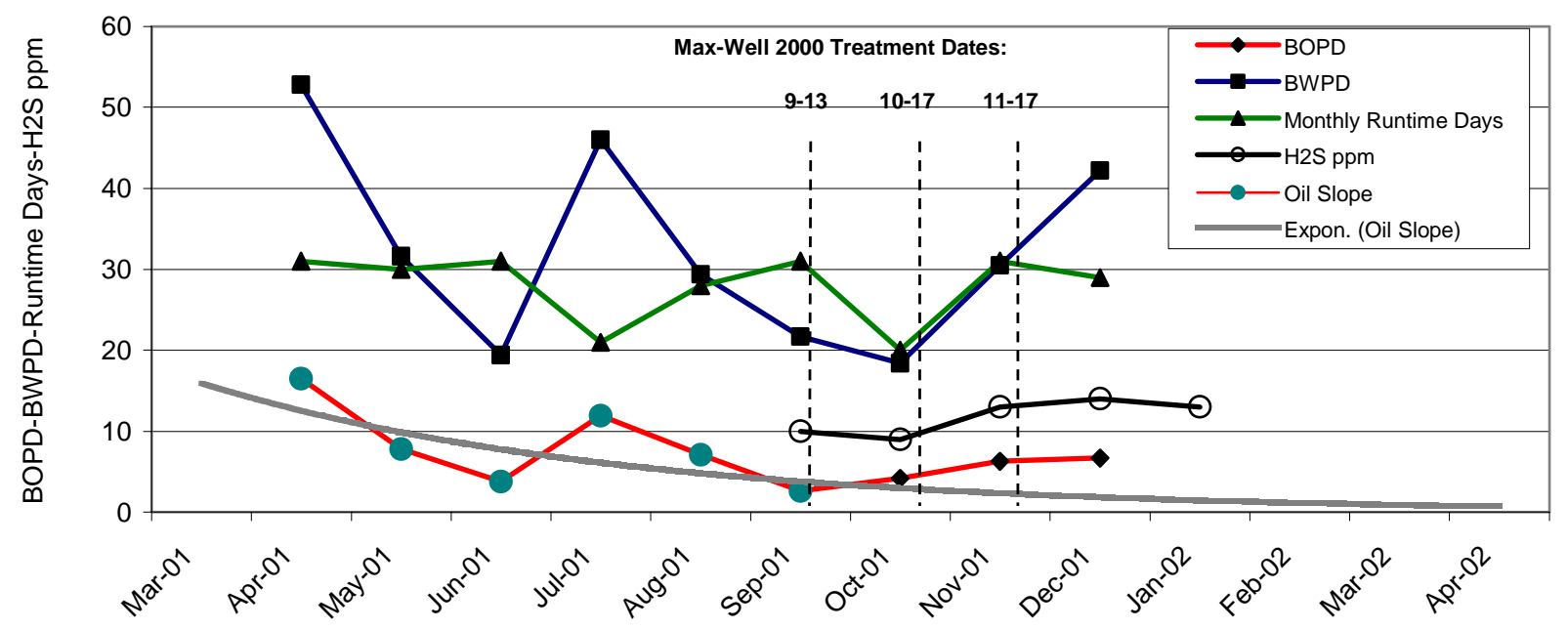

Figure 39. Belridge test well 7361A.

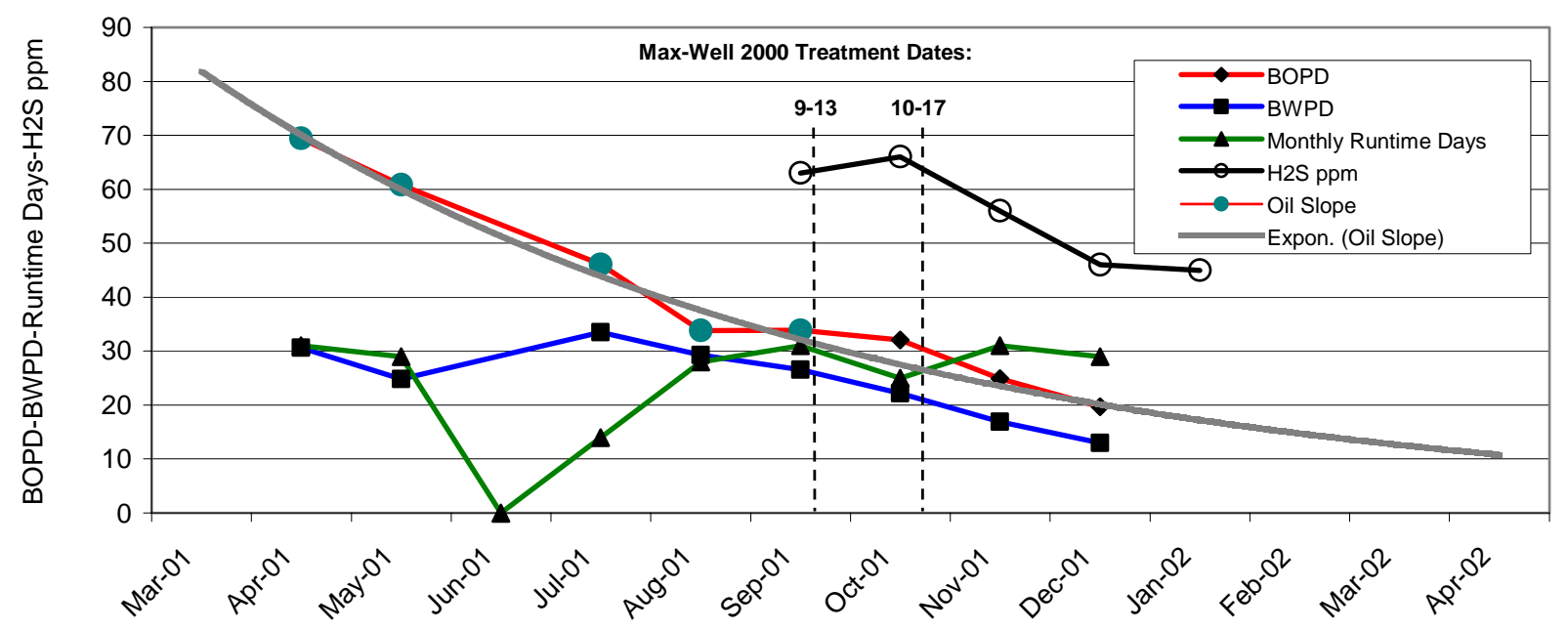

Figure 40. Belridge test well 7404. 


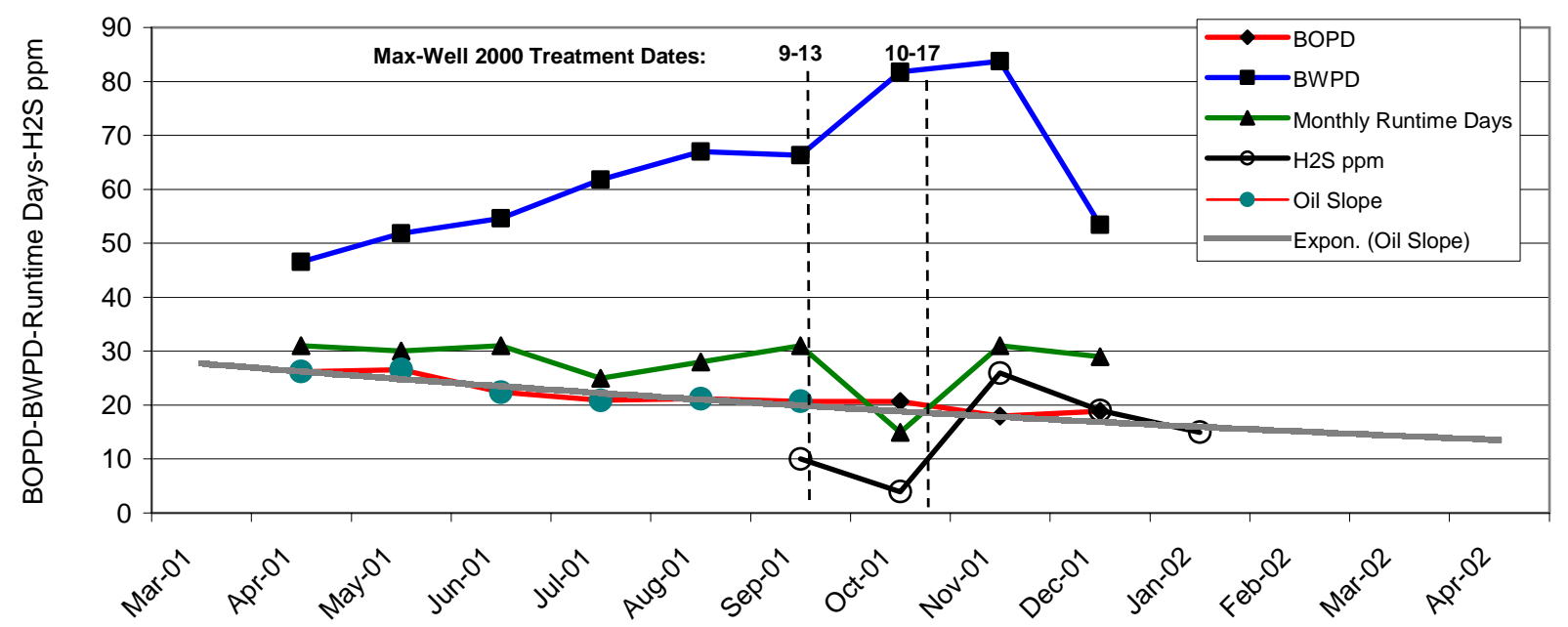

Figure 41. Belridge test well 7407.

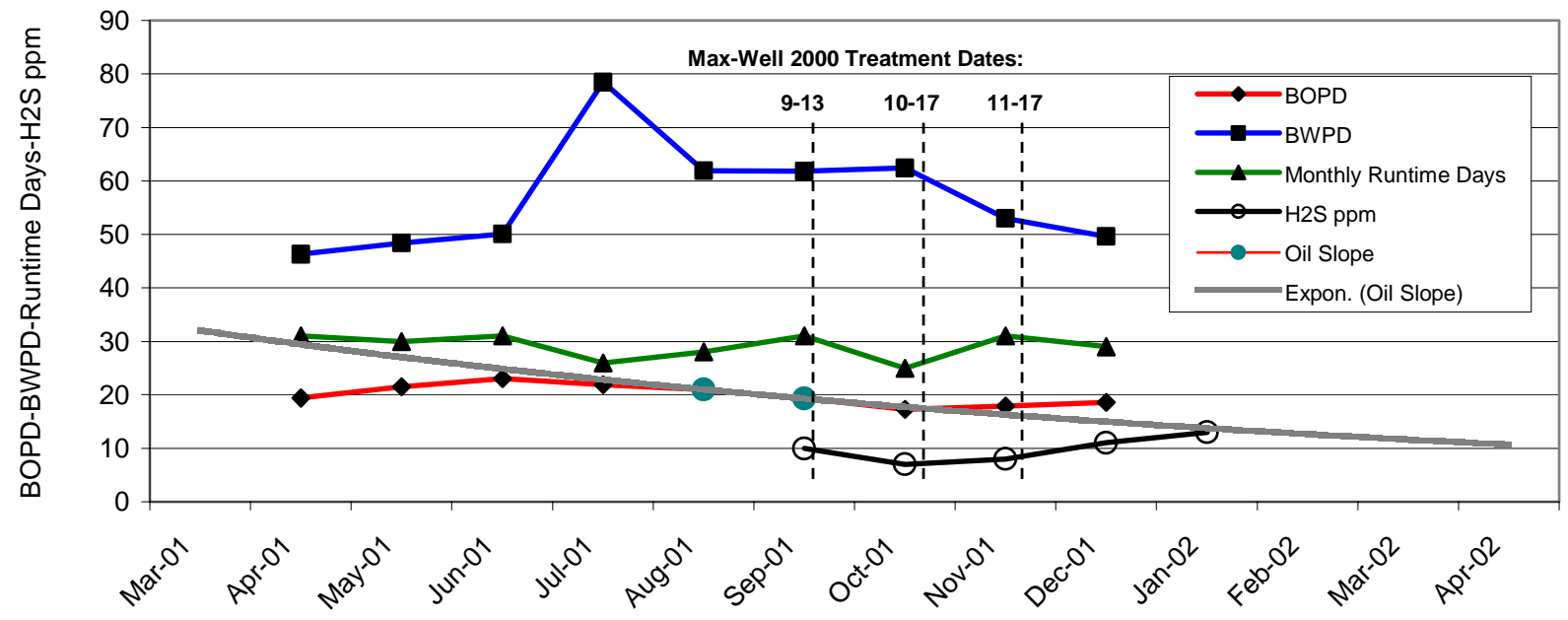

Figure 42. Belridge test well 8383. 


\section{CHAPTER 4}

\section{Reports and Technology Transfer}

\section{Introduction}

Reports have been issued semiannually, and will also be published in a final comprehensive report. Reports will be issued and offered to industry.

The fourth Semi-Annual report was delivered on schedule.

\section{Presentations and publications}

Hitzman, D. O. and S. A. Bailey. 2000. Innovative MIOR Process Utilizing Indigenous Reservoir Constituents. DOE Semi-Annual Report, January 2000.

Hitzman, D. O., S. A. Bailey, and A. K. Stepp. 2000. Innovative MIOR Process Utilizing Indigenous Reservoir Constituents. DOE Semi-Annual Report, July 2000.

A presentation on the project was made at the Oil Technology Program Contractor Review Meeting in Denver in June 2000 by Scott Bailey.

Hitzman, D. O. and A. K. Stepp. 2001. Innovative MIOR Process Utilizing Indigenous Reservoir Constituents. DOE Semi-Annual Report, January 2001.

Hitzman, D. O., A. K. Stepp, D. M. Dennis, and L. R. Graumann. 2001. Innovative MIOR Process Utilizing Indigenous Reservoir Constituents. DOE Semi-Annual Report, October 2001.

\section{Presentations as part of GMT Exhibit Booth}

Society of Geophysicists (SEG) Annual Convention, October 31-November 5, 1999, Houston.

GEO 2000, Middle East Oil and Gas Exposition, March 27-29, 2000, Bahrain.

Society of Petroleum Engineers (SPE) DOE Improved Oil Recovery Symposium, April 2-5, 2000, Tulsa.

American Association of Petroleum Geologists (AAPG) Annual Convention, April 16-19, 2000, New Orleans.

NAPE (North American Prospect Exposition), January 31-February 1, 2001, Houston.

AAPG, March 9-13, 2001, Dallas.

SPE, March 24-27, 2001, Oklahoma City. 
Oklahoma Geological Survey, May 8-9, 2001, Oklahoma City.

AAPG Annual Convention, June 2-7, 2001, Denver.

CSPG (Canadian Society for Petroleum Geologists), Annual Convention, June 16-20, 2001, Calgary.

SEG Annual Convention, September 9-12, 2001, New Orleans.

AAPG East Section Meeting, September 23-25, 2001, Kalamazoo, Michigan.

NAPE, January 29-31, 2002, Houston.

AAPG Annual Convention, March 10-13, 2002, Houston.

Kansas Geological Society, March 28, 2002, Wichita, KS. 


\section{REFERENCES}

1. ZoBell, C. E. 1946. Bacteriological Process for Treatment of Fluid-Bearing Earth Formations. U.S. Patent No. 2,413,278.

2. Hitzman, D. O. 1962. Microbiological secondary recovery of petroleum. U.S. Patent No. $3,032,472$

3. Hitzman, D. O. 1983. Petroleum Microbiology and the History of Its Role in Enhanced Oil Recovery. Proc. of the 1982 International Conference on Microbial Enhancement of Oil Recovery, Afton, OK, May 16 - 21, 1982.

4. Sperl, G. T., P. L. Sperl, and D. O. Hitzman. 1993. Use of Natural Microflora, Electron Acceptors and Energy Sources for Enhanced Oil Recovery, In: E. T. Premuzic and A. Woodhead (ed.), Microbial Enhancement of Oil Recovery - Recent Advances, Elsevier Science Publishers, New York, NY. 